\title{
Ultra-thin Fe3C nanosheets promote the adsorption and conversion of polysulfides in lithium-sulfur batteries
}

DOI:

10.1016/j.ensm.2018.08.016

\section{Document Version}

Accepted author manuscript

Link to publication record in Manchester Research Explorer

\section{Citation for published version (APA):}

Li, H., Ma, S., Cai, H., Zhou, H., Huang, Z., Hou, Z., Wu, J., Yang, W., Yi, H., Fu, C., \& Kuang, Y. (2019). Ultra-thin $\mathrm{Fe}_{3} \mathrm{C}$ nanosheets promote the adsorption and conversion of polysulfides in lithium-sulfur batteries. Energy Storage Materials, 18, 338-348. https://doi.org/10.1016/j.ensm.2018.08.016

\section{Published in:}

Energy Storage Materials

\section{Citing this paper}

Please note that where the full-text provided on Manchester Research Explorer is the Author Accepted Manuscript or Proof version this may differ from the final Published version. If citing, it is advised that you check and use the publisher's definitive version.

\section{General rights}

Copyright and moral rights for the publications made accessible in the Research Explorer are retained by the authors and/or other copyright owners and it is a condition of accessing publications that users recognise and abide by the legal requirements associated with these rights.

\section{Takedown policy}

If you believe that this document breaches copyright please refer to the University of Manchester's Takedown Procedures [http://man.ac.uk/04Y6Bo] or contact uml.scholarlycommunications@manchester.ac.uk providing relevant details, so we can investigate your claim.

\section{OPEN ACCESS}




\section{Author's Accepted Manuscript}

Ultra-thin $\mathrm{Fe}_{3} \mathrm{C}$ Nanosheets Promote the Adsorption and Conversion of Polysulfides in Lithium-Sulfur Batteries

Huanxin Li, Shuai Ma, Houqin Cai, Haihui Zhou, Zhongyuan Huang, Zhaohui Hou, Jiajing Wu, Wenji Yang, Haibo Yi, Chaopeng Fu, Yafei Kuang

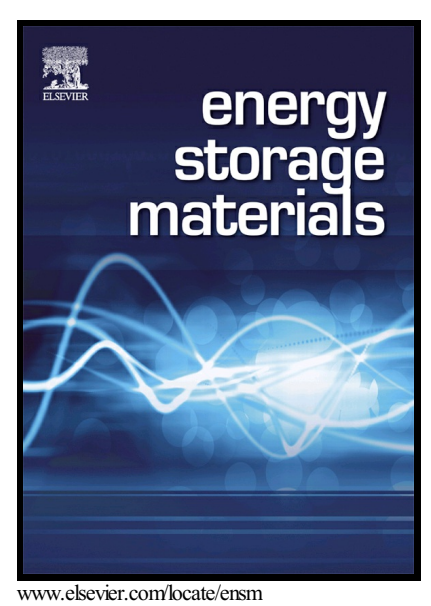

PII: $\quad$ S2405-8297(18)30729-3

DOI: $\quad$ https://doi.org/10.1016/j.ensm.2018.08.016

Reference: ENSM483

To appear in: Energy Storage Materials

Received date: 8 June 2018

Revised date: 19 August 2018

Accepted date: 19 August 2018

Cite this article as: Huanxin Li, Shuai Ma, Houqin Cai, Haihui Zhou, Zhongyuan Huang, Zhaohui Hou, Jiajing Wu, Wenji Yang, Haibo Yi, Chaopeng Fu and Yafei Kuang, Ultra-thin $\mathrm{Fe}_{3} \mathrm{C}$ Nanosheets Promote the Adsorption and Conversion of Polysulfides in Lithium-Sulfur Batteries, Energy Storage Materials, https://doi.org/10.1016/j.ensm.2018.08.016

This is a PDF file of an unedited manuscript that has been accepted for publication. As a service to our customers we are providing this early version of the manuscript. The manuscript will undergo copyediting, typesetting, and review of the resulting galley proof before it is published in its final citable form. Please note that during the production process errors may be discovered which could affect the content, and all legal disclaimers that apply to the journal pertain. 


\section{Ultra-thin $\mathrm{Fe}_{3} \mathrm{C}$ Nanosheets Promote the Adsorption and Conversion of Polysulfides in Lithium-Sulfur Batteries}

Huanxin Li, ${ }^{a, b}$ Shuai Ma, ${ }^{a, b}$ Houqin Cai, ${ }^{a, b}$ Haihui Zhou, ${ }^{a, b^{*}}$ Zhongyuan Huang, ${ }^{a, b}$ Zhaohui Hou, ${ }^{c,}{ }^{*}$ Jiajing $W u,{ }^{d}$ Wenji Yang, ${ }^{e}$ Haibo Yi, ${ }^{a, b,{ }^{*}}$ Chaopeng Fu, ${ }^{a, b}$ Yafei Kuang $^{a, b^{*}}$

${ }^{a}$ State Key Laboratory for Chemo/Biosensing and Chemometrics, Hunan University, Changsha, 410082, China

${ }^{\mathrm{b}}$ College of Chemistry and Chemical Engineering, Hunan University, Changsha, 410082, China

${ }^{\mathrm{c}}$ School of Chemistry and Chemical Engineering, Hunan Institute of Science and Technology, Yueyang, 414006, China

${ }^{\mathrm{d}}$ Hefei National Laboratory for Physical Sciences at the Microscale, CAS Center for Excellence in Nanoscience, and CAS Key Laboratory of Mechanical Behavior and Design of Materials, University of Science and Technology of China, Hefei, Anhui, 230026, China

${ }^{\mathrm{e}}$ School of Materials, The University of Manchester, Oxford Road, Manchester, M13 9PL, United Kingdom 


\title{
Ultra-thin $\mathrm{Fe}_{3} \mathrm{C}$ Nanosheets Promote the Adsorption
}

\section{and Conversion of Polysulfides in Lithium-Sulfur}

\section{Batteries}

\begin{abstract}
Rational design of hierarchical porous materials with comprehensive properties, e.g. good conductivity, fine dispersibility for sulfur, strong adsorption and catalytic abilities to polysulfides (LiPSs), is urgently needed for the practical application of lithium-sulfur batteries (Li-S batteries). Here, based on density functional theory (DFT) computational results and the design concept of efficient, low-cost and environmental friendliness, we report an ultra-thin $(\sim 1 \mathrm{~nm}) \mathrm{Fe}_{3} \mathrm{C}$ nanosheets growing on mesoporous carbon $\left(\mathrm{Fe}_{3} \mathrm{C}-\mathrm{MC}\right)$ with large specific surface area of $686.9 \mathrm{~m}^{2} \mathrm{~g}^{-1}$ and pore volume of $6.52 \mathrm{~cm}^{3} \mathrm{~g}^{-1}$. Meanwhile, the formation mechanism of two-dimensional $\mathrm{Fe}_{3} \mathrm{C}$ is revealed according to DFT results. In the $\mathrm{Fe}_{3} \mathrm{C}-\mathrm{MC}$ composite, the mesoporous carbon constructs a conductive network for dispersion of sulfur species, while $\mathrm{Fe}_{3} \mathrm{C}$ nanosheets play a key role in electronic transmission, LiPSs adsorption and conversion in Li-S batteries. As a result, the $\mathrm{Fe}_{3} \mathrm{C}$ MC composite delivers a high initial capacity of $1530 \mathrm{~mA} \mathrm{~h} \mathrm{~g}^{-1}$ at $0.1 \mathrm{C}$, and a capacity of $699 \mathrm{~mA} \mathrm{~h} \mathrm{~g}^{-1}$ after 100 cycles at $0.5 \mathrm{C}$ at a super-high sulfur loading of 9.0 $\mathrm{mg} \mathrm{cm}{ }^{-2}$, meaning a specific area capacity of $6.291 \mathrm{~mA} \mathrm{~h} \mathrm{~cm}^{-2}$. Such sulfur host is expected to accelerate the practical applications of Li-S batteries benefiting from the low-cost and large-scale process.
\end{abstract}

KEYWORDS: Biomass source, heat treatment, $\mathrm{Fe}_{3} \mathrm{C} @$ mesoporous carbon, multifunctional sulfur host, Li-S batteries 
Lithium-sulfur batteries have attracted considerable attention as one of the most promising next generation energy storage systems due to the high theoretical specific capacity $\left(1675 \mathrm{mAh} \mathrm{g}^{-1}\right)$ and high energy density $\left(2600 \mathrm{~W} \mathrm{~h} \mathrm{~kg}^{-1}\right) .{ }^{1-3}$ However, the commercialization of Li-S batteries is hindered by the poor cycle stability and inadequate capacity ${ }^{4-6}$ resulting from poor electrical conductivity of sulfur, the "shuttle effect" and slow redox reaction of soluble lithium polysulfides.

Many efforts have been made in order to solve these problems. As for the poor conductivity of sulfur, dispersing sulfur into highly conductive materials is an efficient way. Up to now, carbon material is the mainstreamed conductive material being used as sulfur host, which is widely reported. ${ }^{4,7}$ The sulfur/carbon cathode composite materials display promising initial capacity for $\mathrm{Li}-\mathrm{S}$ batteries owning to the high conductivity of carbon materials. However, the simple mixing strategy is not enough to address the "shuttle effect" which often leads to rapid decay of the capacity for Li-S batteries. Furthermore, structure-designed carbon materials like carbon nanocages, ${ }^{9}$ carbon nanotubes ${ }^{10}$ and mesoporous carbon ${ }^{11}$ are prepared to physically shield the LiPS shuttling. In this strategy, sulfur species are generally trapped in a relatively enclosed space to prevent the LiPSs from shuttling. However, the physical shield effect of cage-type structure inevitably separate the electrolytes from contacting active sulfur as well, resulting in poor rate capacities.

The "shuttle effect" is a key issue that needs to be solved urgently. The dissolution of LiPSs in the electrolyte and the transmission between electrodes cause serious loss of capacity and unsatisfied cycle stability. The compounds with strong adsorption ability are often used to capture the LiPSs and prevent them from shuttling. Chemical adsorption is an efficient strategy used to block LiPSs shuttling. Among all 


\section{ACCEPTED MANUSCRIPT}

the functional carbon composites, materials with more open structure like wrinkled nanosheets (doped graphene, ${ }^{12,13}$ black phosphorus, ${ }^{14} \mathrm{C}_{3} \mathrm{~N}_{4}$ etc. ${ }^{3,15}$ ) ensure the infiltration of electrolyte and display more promising rate capacity. Meanwhile, chemical adsorption has a stronger adsorption force and thereby a more efficient fixation effect on LiPSs. Previously, our group prepared an N-doped CNTs@mesoporous carbon composite by fully using the trace iron source in biomass waste and additional nitrogen precursor, which demonstrated a cathodic sulfur host with strong chemical adsorption to LiPSs and thereby displayed promising performance for Li-S batteries. ${ }^{7}$ However, the limited adsorption sites, cannot meet the need for adsorption of large amount of LiPSs. Further, chemical adsorption can be a more efficient solution when combined with LiPSs fast conversion into an insoluble sulfide.

Another strategy to block the "shuttle effect" is to accelerate the conversion of soluble LiPSs to shorten the existence time of LiPSs and thereby reduce the possibility of their shuttling. This strategy requires the sulfur host possess not only adsorption ability but also excellent electrochemical catalytic ability to LiPSs. Recently, various transition metal compounds $\left(\mathrm{Co}_{4} \mathrm{~N},{ }^{16} \mathrm{TiN} / \mathrm{TiO}_{2}{ }^{17,}{ }^{18}\right.$ and $\mathrm{Co}-\mathrm{N}-$ $\mathrm{GC}^{19}$ ) have been reported to possess promising catalytic performance for LiPSs' fast conversion. Dong et al. ${ }^{20}$ revealed that the Co-N synergistically enhanced Li-S performance, as Co helps to transform long-chain LiPSs to short-chain ones and doped-nitrogen is apt to facilitate the oxidation of LiPSs to $S_{8}$. Furthermore, Dong et al. ${ }^{16}$ also designed a $\mathrm{Co}_{4} \mathrm{~N}$ mesoporous sphere with superior performance for Li-S batteries even at ultra-high sulfur content ( 95\%). Yang et al. ${ }^{17}$ reported a twinborn $\mathrm{TiO}_{2}-\mathrm{TiN}$ heterostructure to realize the trapping-diffusion-conversion of LiPSs for ultra-long life Li-S batteries. These report revealed the important role of polar 


\section{ACCEPTED MANUSCRIPT}

transition metal compounds as sulfur host for Li-S batteries, i.e. efficient capture and rapid conversion of LiPSs. Nevertheless, the polar transition metal compounds often possess relative low specific surface area. To sum up, the sulfur host with excellent performances should possess the comprehensive properties: 1. High conductivity; 2. Larger specific surface area for sulfur dispersion; 3. Strong adsorption to LiPSs; 4. Excellent catalytic ability for LiPSs conversion, as well as 5. Low-cost and environmental friendliness.

As we know, iron $(\mathrm{Fe})$ is a common transition metal element, which has been widely used in many fields because of its abundant reserve, low cost, non-toxicity, good biocompatibility and natural catalytic activity. Meanwhile, biomass waste is also a kind of low-cost renewable carbon source which can be easily obtained in a large scale. According to the required properties for sulfur host as well as the considerations above, we conducted DFT calculations to predict the possible structure, conductivity, adsorption and catalytic abilities to LiPSs of $\mathrm{Fe}_{3} \mathrm{C}$. The DFT results indicate that $\mathrm{Fe}_{3} \mathrm{C}$ tends to form a two-dimensional structure in high temperature deposition process, and it might possess a strong adsorption and catalytic ability to LiPSs as most of transition metal compounds do. The adsorption to LiPSs inhibits the migration of LiPSs while the catalytic effects accelerate the conversion, both of which can restrict the "shuttle effect". Therefore, we aim at designing and synthesizing a two-dimensional $\mathrm{Fe}_{3} \mathrm{C} /$ mesoporous carbon composite with high conductivity, large specific surface area, strong adsorption ability and excellent catalytic activity using iron compound and biomass as precursors to LiPSs to realize high-performance sulfur host for Li-S batteries with excellent stability. In our designing strategy, the mesoporous carbon can be obtained through annealing biomass waste and the polar conductive $\mathrm{Fe}_{3} \mathrm{C}$ also can be formed by adding $\mathrm{Fe}$ sources into biomass at annealing process. The $\mathrm{Fe}_{3} \mathrm{C}$ can 


\section{ACCEPTED MANUSCRIPT}

provide sufficient active sites for the adsorption and conversion of LiPSs. Thus, the designed $\mathrm{Fe}_{3} \mathrm{C} /$ mesoporous carbon composite should address the major issues mentioned above effectively.

Herein, the $\mathrm{Fe}_{3} \mathrm{C}-\mathrm{MC}$ composite was prepared by the specific process as follows: biomass waste corncob, used as carbon source, was pretreated by concentrated sulfuric acid and then mixed with Fe precursor ferrous sulfate. Finally, the mixture was annealed at $800{ }^{\circ} \mathrm{C}$ under nitrogen atmosphere and $\mathrm{Fe}_{3} \mathrm{C}-\mathrm{MC}$ composite was obtained. The resultant composite $\left(\mathrm{Fe}_{3} \mathrm{C}-\mathrm{MC}\right)$ displays a hierarchical structure with ultra-thin two-dimensional $\mathrm{Fe}_{3} \mathrm{C}$ nanosheets growing on mesoporous carbon (MC) material. The formation mechanism of the two-dimensional $\mathrm{Fe}_{3} \mathrm{C}$ nanosheets is investigated based on DFT calculations. Meanwhile, DFT results also indicate that $\mathrm{Fe}_{3} \mathrm{C}$ is a conductive polar compound with strong adsorption ability and excellent activation ability to LiPSs, which might promote the capture and transformation of LiPSs. When the three-dimensional hierarchical conductive $\mathrm{Fe}_{3} \mathrm{C}-\mathrm{MC}$ composite is used as sulfur host for Li-S batteries, it facilitates the electronic/ionic transportation, captures LiPSs to retard "shuttle effect" and enhances the reaction kinetics simultaneously. The $\mathrm{Fe}_{3} \mathrm{C}-\mathrm{MC}$ cathode delivers a high capacity and superior longterm stability for Li-S batteries even at high sulfur content and high sulfur loading. Such a sulfur host is expected to promote the practical use of Li-S batteries because of the low cost of raw sources and simple process. The approach for the sulfur host preparation also suggests a new way to produce multifunctional sulfur host to improve the performance of energy storage device in a large scale.

\section{RESULTS AND DISCUSSION}




\section{ACCEPTED MANUSCRIPT}

The expected $\mathrm{Fe}_{3} \mathrm{C}$-MC composite was synthesized by a facile pyrolysis method, as presented in Figure 1a. Firstly, the cleaned corncobs were firstly ball milled into fine powders with a diameter of about $1 \mathrm{~mm}$ (Figure S4). Then the corncob powders were pretreated with concentrated sulfuric acid to activate the radicals and remove excess hydrogen and oxygen on corncobs. In previous researches, the biomass source is directly calcined or pre-activated by $\mathrm{ZnCl}_{2}, \mathrm{KOH}, \mathrm{K}_{2} \mathrm{CO}_{3}$, etc. to generate mesoporous structure. ${ }^{31-35}$ Pretreatment by concentrated sulfuric acid is different from the processes previously reported, in which the C-H and C-O bonds would break before $\mathrm{C}-\mathrm{C}$ bonds due to strong dehydration of concentrated sulfuric acid to preserve the carbon source, and the structure and composition of biomass significantly change (Figure S5). ${ }^{7}$ After thoroughly washed, the pretreated corncob powders were homogeneously mixed with $\mathrm{FeSO}_{4}$. Finally, the mixture was heat treated at $800{ }^{\circ} \mathrm{C}$ for 2 hours and the $\mathrm{Fe}_{3} \mathrm{C}-\mathrm{MC}$ composite was obtained (Figure S3). For comparison, $\mathrm{MC}$ was also prepared by carbonizing the pretreated corncob directly without $\mathrm{FeSO}_{4}$ addition. As demonstrated in Figure 1b, the pretreated biomass displayed a loose structure of cross-linked fiber chains. Then, the added $\mathrm{FeSO}_{4}$ was adsorbed on the fiber chains and stored in the pores. During heat treatment, part of the biomass decomposed into small gaseous molecules and the concentration of Fe in carbon matrix increased. As a result, the $\mathrm{Fe}$ atoms crystallized out while $\mathrm{C}$ atoms permeated into the crystals, forming $\mathrm{Fe}_{3} \mathrm{C}$ nanosheets. To better understand the formation mechanism of the two-dimensional $\mathrm{Fe}_{3} \mathrm{C}$, we calculated the surface energies of three mutually perpendicular planes on $\mathrm{Fe}_{3} \mathrm{C}$ (Figure 1c). It is well known that the crystals tend to grow on planes with larger surface energies to minimize the energy of whole system, especially at high temperature. The surface energies of $\left(\begin{array}{lll}0 & 0 & 2\end{array}\right)$ and $\left(\begin{array}{lll}-2 & 2 & 0\end{array}\right)$ planes are 15.74 and $9.02 \mathrm{eV}$, respectively, while that of (2 20$)$ plane is $4.85 \mathrm{eV}$. 


\section{ACCEPTED MANUSCRIPT}

Therefore, the Fe and $\mathrm{C}$ atoms are more likely to be deposited on $\left(\begin{array}{lll}0 & 0 & 2\end{array}\right)$ and $\left(\begin{array}{lll}-2 & 2 & 0\end{array}\right)$ planes while the deposition on (2 20 ) plane is prohibited at annealing process, forming two-dimensional $\mathrm{Fe}_{3} \mathrm{C}$ nanosheets. In the end, the $\left(\begin{array}{lll}0 & 0 & 2\end{array}\right)$ and $\left(\begin{array}{lll}-2 & 2 & 0\end{array}\right)$ planes disappeared while the (2 20 ) plane exposed in the final $\mathrm{Fe}_{3} \mathrm{C}$ nanosheets.

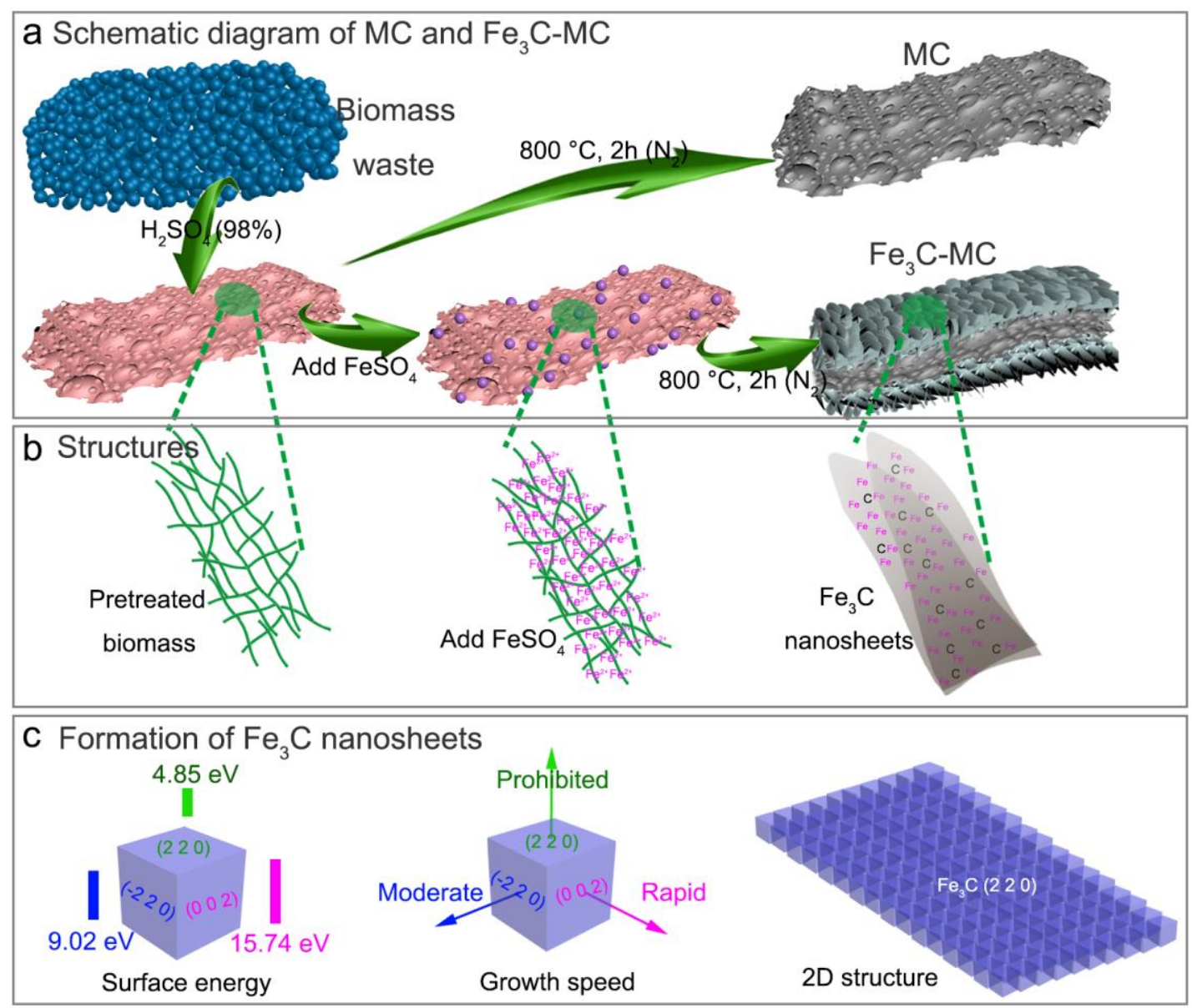

Figure 1. (a) The schematic diagram for synthesis of $\mathrm{MC}$ and $\mathrm{Fe}_{3} \mathrm{C}-\mathrm{MC}$; (b) Structural schematic diagram for the formation of $\mathrm{Fe}_{3} \mathrm{C}$ nanosheets; (c) Formation mechanism of $\mathrm{Fe}_{3} \mathrm{C}$ nanosheets

Then, DFT calculation was performed to predict the possible trapping and conversion ability of $\mathrm{Fe}_{3} \mathrm{C}$ for LiPSs. The $\mathrm{Li}_{2} \mathrm{~S}_{6}$ was selected as a representative prototype molecule for modelling. The optimized free $\mathrm{Li}_{2} \mathrm{~S}_{6}$ molecule displays a structure of deformation crown. ${ }^{26}$ Figure 2a demonstrates the optimized geometric structure and bonding state when $\mathrm{Li}_{2} \mathrm{~S}_{6}$ is adsorbed on the $\mathrm{Fe}_{3} \mathrm{C}$ surface. The favorable binding sites are the two $\mathrm{S}$ atoms at the bottom, with each $\mathrm{S}$ atom being strongly 


\section{ACCEPTED MANUSCRIPT}

bonded with three $\mathrm{Fe}$ atoms. The $\mathrm{Li}$ atoms are away from the $\mathrm{Fe}_{3} \mathrm{C}$ surface to reduce the electrostatic repulsion of iron atoms. The calculated adsorption energy of $\mathrm{Li}_{2} \mathrm{~S}_{6}$ on $\mathrm{Fe}_{3} \mathrm{C}$ surface is $-3.85 \mathrm{eV}$ (energies of $E_{a d s}, E_{t o l}, E_{L S}$ and $E_{\text {sur }}$ are illustrated in Table S1), indicating that $\mathrm{Fe}_{3} \mathrm{C}$ possesses excellent adsorption ability for LiPSs. ${ }^{27}$ The representative reported adsorption energy results are illustrated in Table S3, revealing the superior adsorption ability of $\mathrm{Fe}_{3} \mathrm{C}$ compared with the other adsorbents. ${ }^{28,29}$ The bond length of $\mathrm{Li}_{2} \mathrm{~S}_{6}$ before and after adsorption was also calculated by DFT. Figure S2 shows the length of all the bonds, in the optimized free $\mathrm{Li}_{2} \mathrm{~S}_{6}$ molecule, all the $\mathrm{S}-\mathrm{S}$ bonds are 2.059-2.104 $\AA$ while Li-S bonds are 2.344-2.411 $\mathrm{A}$. However, after adsorption, two S-S bonds have changed obviously (Bond 1 and Bond 2 as pointed out). The states of the two $\mathrm{S}-\mathrm{S}$ bonds before and after adsorption on $\mathrm{Fe}_{3} \mathrm{C}$ are shown in Figure 2b. In bond 1, the initial length of S-S bond is $2.059 \AA$. After adsorption on $\mathrm{Fe}_{3} \mathrm{C}$, the $\mathrm{S}-\mathrm{S}$ bond 1 is activated (almost broken) as the distance between the two $\mathrm{S}$ atoms has changed to $3.348 \AA$. In another S-S bond (bond 2), the length is 2.014 and $2.486 \AA$ before and after adsorption, respectively, also indicating activation by $\mathrm{Fe}_{3} \mathrm{C}$. The increase of the length of S-S bonds demonstrates the bond energies are reduced, which means the $\mathrm{Li}_{2} \mathrm{~S}_{6}$ molecule is in an activated state and more prone to reaction. ${ }^{29}$ The DFT calculation suggests that the $\mathrm{Fe}_{3} \mathrm{C}$ might possess not only superior adsorption ability to LiPSs, but also excellent catalytic effect for LiPSs fast transformation. ${ }^{30}$ 


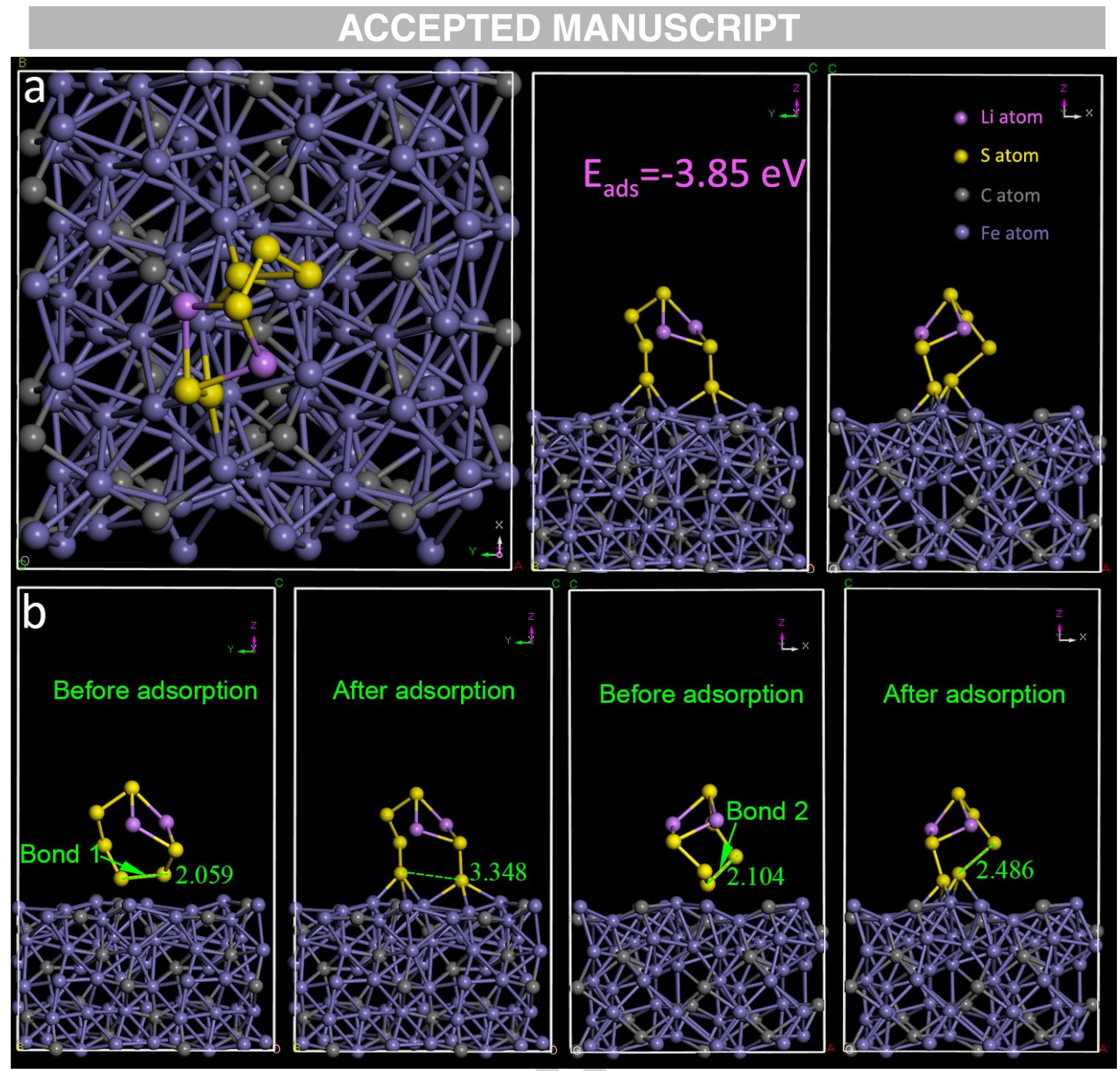

Figure 2. (a) Optimized geometries (top view, front view and side view) of $\mathrm{Li}_{2} \mathrm{~S}_{6}$ on orthogonal $\mathrm{Fe}_{3} \mathrm{C}$ and (b) the geometric deformation and bond length (bond 1 and bond 2) of $\mathrm{Li}_{2} \mathrm{~S}_{6}$ before and after adsorption

Then the influence factors for forming $\mathrm{Fe}_{3} \mathrm{C}$ nanosheets were investigated. Variety of samples was annealed at different temperatures with addition of different $\mathrm{FeSO}_{4}$ concentration. The SEM images of samples with and without $\mathrm{FeSO}_{4}$ addition are shown in Figure S6. The samples annealed with $\mathrm{FeSO}_{4}$ addition exhibit ordered ultra-thin squamae-like nanosheets on the surface (Figure S6a-c). The directly annealed sample without $\mathrm{FeSO}_{4}$ addition displays typical loose mesoporous carbon morphology with plenty of folds on the surface (Figure S6d-f). Further, the XRD results of the products obtained under different conditions are illustrated in Figure 


\section{ACCEPTED MANUSCRIPT}

S7a. It can be deduced that when the annealing temperature is lower than $750{ }^{\circ} \mathrm{C}$ or the Fe concentration is below 0.06 wt. \%, the Fe source tends to combine with the small amount of oxygen contained in biomass and generates $\mathrm{Fe}_{2} \mathrm{O}_{3} / \mathrm{C}$ composite. But when the annealing temperature is higher than $950^{\circ} \mathrm{C}$ or the Fe concentration is above $3.3 \%$, the Fe source is more likely to be reduced and form elementary substance of Fe. The most appropriate condition for the generation of $\mathrm{Fe}_{3} \mathrm{C}$ is annealing at 750-950 ${ }^{\circ} \mathrm{C}$ with Fe concentration of 0.1-0.3 wt. \% (Figure S7b).

To reveal the detail structure and composition of the composites, especially for the nanosheets, further analyses on $\mathrm{Fe}_{3} \mathrm{C}-\mathrm{MC}$ composite are shown in Figure 3. The SEM image of the composite in Figure 3a shows that squamae-like $\mathrm{Fe}_{3} \mathrm{C}$ nanosheets are well-wrinkled and ultra-thin, and possess large specific surface area (Figure S8). TEM images in Figure 3b showed the squamae-like $\mathrm{Fe}_{3} \mathrm{C}$ nanosheets and mesoporous carbon actually interspersed together with good connection (Figure S9). Figure 3c shows the HRTEM image of the nanosheets, revealing clear lattice fringes and the characteristic spacing of $0.203 \mathrm{~nm}$, corresponding to the (220) planes of $\mathrm{Fe}_{3} \mathrm{C}$ (more details see Figure S10). ${ }^{39}$ The AFM image of $\mathrm{Fe}_{3} \mathrm{C}$ nanosheets reveals a lamellar structure (Figure 3d) and the thickness of the nanosheets is $\sim 1.0 \mathrm{~nm}$, indicating that the $\mathrm{Fe}_{3} \mathrm{C}$ nanosheets are ultra-thin with only $\sim 10$ atomic layers. The EDS analysis on the ultra-thin nanosheet area, as demonstrated in Figure 3e, reveals the $\mathrm{Fe}$ to $\mathrm{C}$ atomic ratio of approximately $3: 1$, again indicating that the nanosheets are composed of $\mathrm{Fe}_{3} \mathrm{C} .{ }^{40}$ The typical TEM image and corresponding elemental mapping of the $\mathrm{Fe}_{3} \mathrm{C}-\mathrm{MC}$ are shown in Figure 3f, revealing that $\mathrm{C}, \mathrm{Fe}$ and $\mathrm{N}$ elements are uniformly dispersed in the composite. The $\mathrm{N}$ might come from the biomass precursors. In Figure 3g, a broad peak of carbon at $2 \theta=20-30^{\circ}$ is observed from the product without $\mathrm{FeSO}_{4}$ addition, indicating that carbon is mainly amorphous. ${ }^{7}$ For the 


\section{ACCEPTED MANUSCRIPT}

product with $\mathrm{FeSO}_{4}$ addition, in addition to the broad carbon peak, sharp peaks at $2 \theta=29.51^{\circ}, 34.21^{\circ}, 40.63^{\circ}, 43.74^{\circ}, 44.57^{\circ}, 48.40^{\circ}$ and $64.81^{\circ}$ are observed, corresponding to the (111), (200), (201), (220), (022), (202) and (321) planes of $\mathrm{Fe}_{3} \mathrm{C}$ (PDF\#35-0772). ${ }^{36}$ Moreover, the surface composition and chemistry of the products prepared with and without $\mathrm{FeSO}_{4}$ addition were analyzed by XPS. For the product without $\mathrm{FeSO}_{4}$ addition, two peaks at $284.6 \mathrm{eV}$ and $401.0 \mathrm{eV}$ corresponding to $\mathrm{C} 1 \mathrm{~s}$ and $\mathrm{N} 1 \mathrm{~s}$ were observed, with atomic ratio of 95.42 at.\% and 4.58 at.\% respectively. For the other one with $\mathrm{FeSO}_{4}$ addition, predominant peaks for $\mathrm{C} 1 \mathrm{~s}, \mathrm{~N}$ 1s and $\mathrm{Fe} 2 \mathrm{p}$ at $284.6 \mathrm{eV}, 401.0 \mathrm{eV}$ and $707.9 \mathrm{eV}$ were detected with atomic ratio of 89.54 at.\%, 4.01 at $\%$ and 6.45 at.\%, indicating the presence of additional Fe element (Figure S11). The nitrogen element might be introduced from the biomass precursor. The high resolution spectrum of $\mathrm{Fe} 2 \mathrm{p}$ (Figure $3 \mathbf{h}$ ) is resolved into two distinguishable peaks at $707.9 \mathrm{eV}$ and $722.6 \mathrm{eV}$, corresponding to the Fe-C bondings (Fe 2p3/2 and $\mathrm{Fe} 2 \mathrm{p} 1 / 2$ )

of $\mathrm{Fe}_{3} \mathrm{C}^{37,38}$ Thus, the composite is confirmed to be composed of mesoporous carbon and $\mathrm{Fe}_{3} \mathrm{C}$ as expected. The content of $\mathrm{Fe}_{3} \mathrm{C}$ in the composite is determinded to be $\sim 23.25 \mathrm{wt} . \%$ according to the TGA test and XRD analysis of the residue after TGA (Figure S12). 


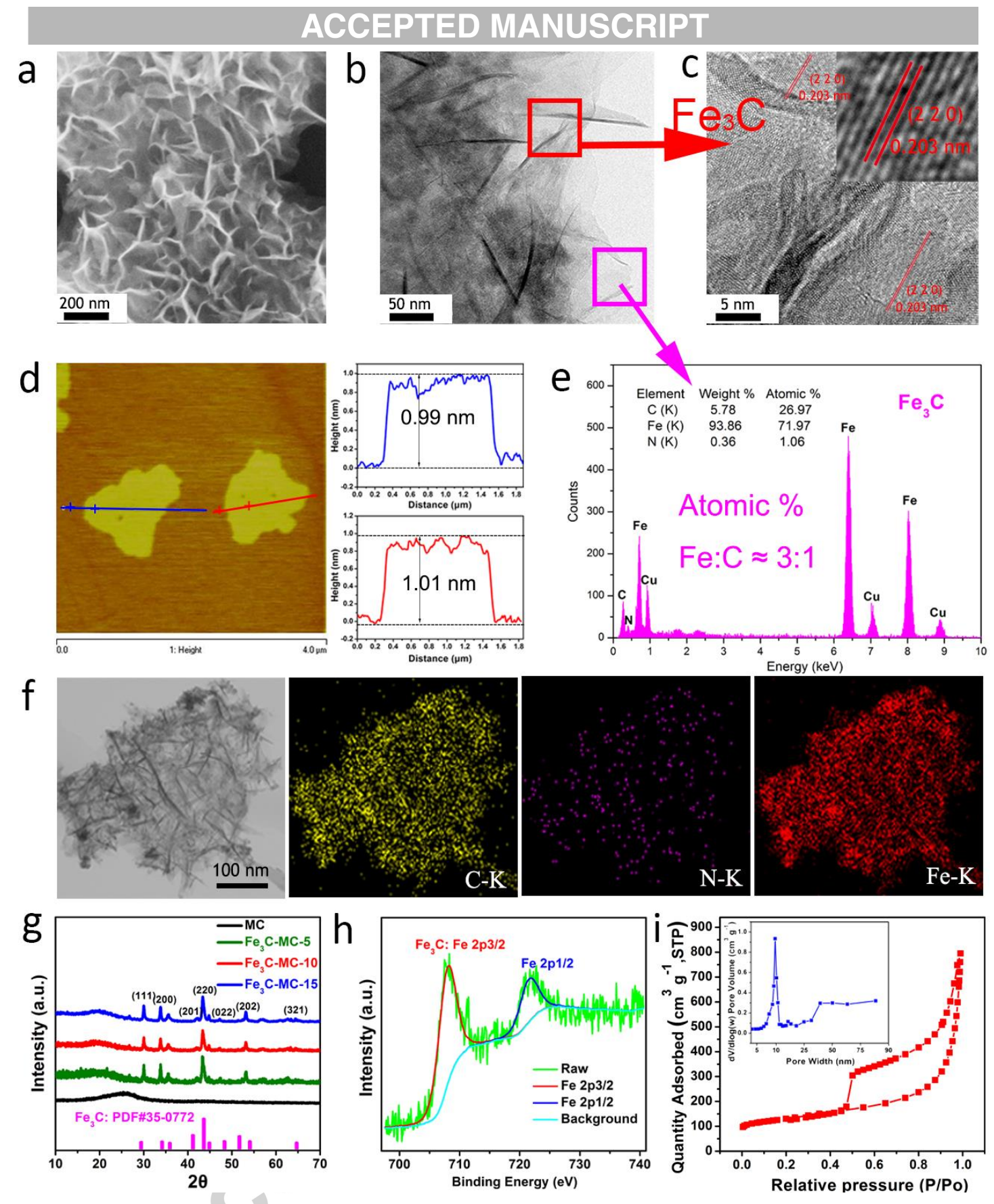

Figure 3. (a) SEM image of $\mathrm{Fe}_{3} \mathrm{C}-\mathrm{MC}$; (b) TEM and (c) HRTEM images of $\mathrm{Fe}_{3} \mathrm{C}-\mathrm{MC}$; (d) AFM image and corresponding thickness analysis of $\mathrm{Fe}_{3} \mathrm{C}-\mathrm{MC}$; (e) $\mathrm{EDS}$ analysis of $\mathrm{Fe}_{3} \mathrm{C}$ nanosheets in composite; (f) TEM image of $\mathrm{Fe}_{3} \mathrm{C}-\mathrm{MC}$ and corresponding EDS mapping images of $\mathrm{C}, \mathrm{N}$ and $\mathrm{Fe}$; (g) XRD patterns of $\mathrm{MC}, \mathrm{Fe}_{3} \mathrm{C}-\mathrm{MC}-5, \mathrm{Fe}_{3} \mathrm{C}-\mathrm{MC}-10, \mathrm{Fe}_{3} \mathrm{C}-\mathrm{MC}-15$; (h) $\mathrm{Fe} \mathrm{XRS}$ high resolution peaks in $\mathrm{Fe}_{3} \mathrm{C}-$ $\mathrm{MC}$; (i) Nitrogen adsorption-desorption isotherms and pore size distributions of $\mathrm{Fe}_{3} \mathrm{C}-\mathrm{MC}$

Further, Brunauer-Emmett-Teller (BET) analysis of $\mathrm{Fe}_{3} \mathrm{C}-\mathrm{MC}$ is illustrated in Figure 3i, demonstrating the isotherms of $\mathrm{Fe}_{3} \mathrm{C}-\mathrm{MC}$ displays closed hysteresis loop. ${ }^{41}$ 


\section{ACCEPTED MANUSCRIPT}

The $\mathrm{Fe}_{3} \mathrm{C}-\mathrm{MC}-10$ possesses a largest specific surface area of $686.9 \mathrm{~m}^{2} \mathrm{~g}^{-1}$ with pore volume of $6.52 \mathrm{~cm}^{3} \mathrm{~g}^{-1}$. The detail isotherms of $\mathrm{Fe}_{3} \mathrm{C}-\mathrm{MC}$ with different ratios are presented is Figure S13a, and the pore size distribution curve of the $\mathrm{Fe}_{3} \mathrm{C}-\mathrm{MC}$ are shown in Figure $\mathbf{S 1 3 b}$, demonstrating fine pores with diameters of $\sim 10 \mathrm{~nm}$ and large pores from 30 to $80 \mathrm{~nm}$. The huge specific surface area facilitates the dispersion of sulfur and the formation of electrochemical reaction interface with the electrolyte to increase the electrochemical capacity of the sulfur cathode. The hierarchical porous structure is very conducive to mitigating the problem of volume expansion during electrochemical redox. To investigate the performance of $\mathrm{Li}-\mathrm{S}$ battery with the $\mathrm{Fe}_{3} \mathrm{C}-$ MC as sulfur host, firstly the $\mathrm{Fe}_{3} \mathrm{C}-\mathrm{MC}$ was mixed with 80 wt. \% sulfur through a typical molten method to prepare $\mathrm{Fe}_{3} \mathrm{C}-\mathrm{MC} / \mathrm{S}$ composite. The SEM and TEM images of $\mathrm{Fe}_{3} \mathrm{C}-\mathrm{MC} / \mathrm{S}$ composite are illustrated in Figure 4. In the SEM image, the squamaelike nanosheet structure of $\mathrm{Fe}_{3} \mathrm{C}$ still can be seen (Figure 4a) although sulfur was mixed into the composite, indicating that sulfur was uniformly dispersed in the composite. In Figure $\mathbf{4 b}$, it is more obvious that the fine sulfur particles are uniformly distributed on the squamae-like $\mathrm{Fe}_{3} \mathrm{C}$ nanosheets. Thus, the mesoporous in $\mathrm{Fe}_{3} \mathrm{C}-\mathrm{MC}$ composite provided large space while the squamae-like nanosheets offered plenty of adsorption sites for sulfur species. Further, the typical TEM image of $\mathrm{Fe}_{3} \mathrm{C}-\mathrm{MC} / \mathrm{S}$ and corresponding mapping images of $\mathrm{C}, \mathrm{N}, \mathrm{Fe}$ and $\mathrm{S}$ are illustrated in Figure $\mathbf{4 c}$ showing that all the elements were evenly distributed in the composite. The intensities of light elements $\mathrm{C}$ and $\mathrm{N}$ are a little weaker while the intensities of $\mathrm{Fe}$ and $\mathrm{S}$ are stronger. Especially, the strong S intensity indicated the sulfur is rich and uniformly dispersed in the composite. Generally, polar metal compounds $\left(\mathrm{MO}_{\mathrm{x}}, \mathrm{MS}_{\mathrm{y}}\right.$ etc., $\mathrm{M}=$ metal element) possess limited conductivity although they exhibit strong adsorption for LiPSs. ${ }^{24,42-52}$ However, the ultra-high electrical conductivity is the primary condition 


\section{ACCEPTED MANUSCRIPT}

that must be satisfied for sulfur host for Li-S batteries. Recently, high-conductivity polar compounds ( $\mathrm{TiN},{ }^{53} \mathrm{Co}_{4} \mathrm{~N}$ etc. ${ }^{16}$ ) as sulfur host with excellent performances have been reported. To assess the conductivity of the sulfur host prepared in the present study, firstly the electrical conductivity of $\mathrm{MC}$ and $\mathrm{Fe}_{3} \mathrm{C}-\mathrm{MC}$ were measured, as illustrated in Table S6 (See Support Information). The MC displayed good conductivity of $0.223 \mathrm{~S} \mathrm{~cm}^{-1}$. Remarkably, the $\mathrm{Fe}_{3} \mathrm{C}-\mathrm{MC}$ showed even better conductivity of $1.067 \mathrm{~S} \mathrm{~cm}^{-1}$, indicating that the interconnected conductive network constructed by $\mathrm{Fe}_{3} \mathrm{C}$ nanosheets is more conductive than $\mathrm{MC}$. Further, the Nyquist plots of batteries with $\mathrm{Fe}_{3} \mathrm{C}-\mathrm{MC}$ and $\mathrm{MC}$ as sulfur hosts are obtained. The diameter of the semicircle at high frequencies reflects the charge transfer resistance $\left(R_{\mathrm{CT}}\right){ }^{7}$ Before cycling, the values of $R_{\mathrm{CT}}$ are estimated to be $\sim 32 \Omega$ and $\sim 60 \Omega$ for $\mathrm{Fe}_{3} \mathrm{C}-\mathrm{MC}$ and $\mathrm{MC}$ respectively, as shown in Figure 4e, indicating faster charge transfer capability of $\mathrm{Fe}_{3} \mathrm{C}-\mathrm{MC}$ than MC. The charge transfer resistances decreased to $\sim 12 \Omega$, and $\sim 32 \Omega$ for $\mathrm{Fe}_{3} \mathrm{C}-\mathrm{MC}$ and $\mathrm{MC}$ respectively after 1000 cycles, as shown in Figure $\mathbf{4 f}$, suggesting that the electrode materials are not fully infiltrated by electrolyte at the beginning. The battery with $\mathrm{Fe}_{3} \mathrm{C}-\mathrm{MC}$ as sulfur host exhibits smaller resistance values both before and after cycling owning to the extremely high electrical conductivity.

Except for the conductivity, strong adsorption ability to LiPSs is also important for sulfur host to block the "shuttle effect" of Li-S batteries. DFT calculation has predicted the strong adsorption ability of $\mathrm{Fe}_{3} \mathrm{C}$ towards LiPSs. ${ }^{29}$ To intuitively reveal the adsorption effects of sulfur host samples to LiPSs, $\mathrm{Li}_{2} \mathrm{~S}_{6}$ was selected as the representative LiPSs. ${ }^{2}$ The $\mathrm{MC}$ and $\mathrm{Fe}_{3} \mathrm{C}-\mathrm{MC}$ were added to the solution of $\mathrm{Li}_{2} \mathrm{~S}_{6}$ in dioxolane (DOL)/dimethoxyethane (DME) solvent, as shown in Figure 4d. The original solution of $\mathrm{Li}_{2} \mathrm{~S}_{6}$ was yellow, and the color of $\mathrm{Li}_{2} \mathrm{~S}_{6}$ solution with $\mathrm{MC}$ became a little lighter but still is yellow, showing a limited adsorption capacity of MC. For the 


\section{ACCEPTED MANUSCRIPT}

$\mathrm{Li}_{2} \mathrm{~S}_{6}$ solution with $\mathrm{Fe}_{3} \mathrm{C}-\mathrm{MC}$, the excellent adsorption ability of the composite is obvious since the yellow $\mathrm{Li}_{2} \mathrm{~S}_{6}$ solution turned into completely colorless. For the $\mathrm{Fe}_{3} \mathrm{C}-\mathrm{MC}$ composite, by penetrating small radius element with low stoichiometric ratio into metal element, high-conductivity and strong-polarity were realized simultaneously. The $\mathrm{C}$ atoms filled in the spacing of $\mathrm{Fe}$ altered the local density of the electronic cloud of Fe and thereby enhanced the polarity, but did not block the electron conduction since the radius of $\mathrm{C}$ atom is small enough. According to the Raman analyses of $\mathrm{Li}_{2} \mathrm{~S}_{6}$ solution and the blank one (Figure $4 \mathrm{~g}$ ), the $\mathrm{Li}_{2} \mathrm{~S}_{6}$ solution displays two additional peaks at 218 and $478 \mathrm{~cm}^{-1}$, corresponding to the characteristic peaks of $\mathrm{Li}_{2} \mathrm{~S}_{6}$. In the Raman spectrum of $\mathrm{Li}_{2} \mathrm{~S}_{6}$ solution with $\mathrm{MC}$ addition, the two peaks at 218 and $478 \mathrm{~cm}^{-1}$ are weaker but still existed, indicating the limited adsorption ability of $\mathrm{MC}$ towards $\mathrm{Li}_{2} \mathrm{~S}_{6}$. With $\mathrm{Fe}_{3} \mathrm{C}-\mathrm{MC}$ adding into $\mathrm{Li}_{2} \mathrm{~S}_{6}$ solution, the characteristic peaks of $\mathrm{Li}_{2} \mathrm{~S}_{6}$ in the Raman spectrum completely disappeared, suggesting that the $\mathrm{Fe}_{3} \mathrm{C}-\mathrm{MC}$ composite possesses superior adsorption ability and capacity for $\mathrm{Li}_{2} \mathrm{~S}_{6}$ and thereby no $\mathrm{Li}_{2} \mathrm{~S}_{6}$ species remained in the solution. ${ }^{16}$ The optical images of the original electrodes and separators and those in $\mathrm{MC} / \mathrm{S}$ and $\mathrm{Fe}_{3} \mathrm{C}-\mathrm{MC} / \mathrm{S}$ batteries after cycling are shown in Figure $\mathbf{4 h}$. Compared to the original electrodes and separators, in the MC/S battery, both electrode and separator adsorbed residual yellow LiPSs. However, in the $\mathrm{Fe}_{3} \mathrm{C}-\mathrm{MC} / \mathrm{S}$ battery, no obvious yellow LiPSs can be observed, indicating the fast conversion of LiPSs on $\mathrm{Fe}_{3} \mathrm{C}-\mathrm{MC}$ composite. 


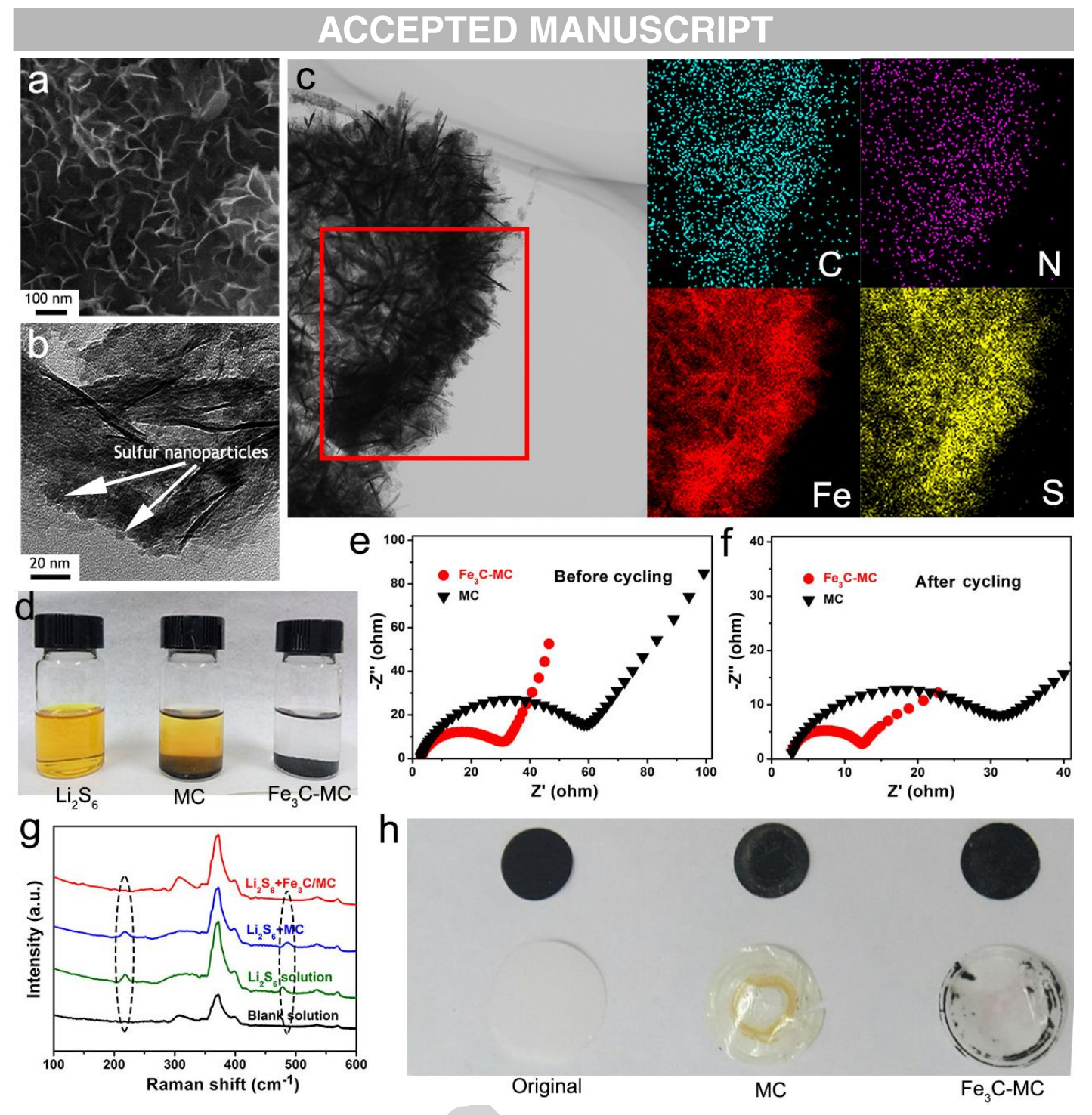

Figure 4. (a) SEM image of $\mathrm{Fe}_{3} \mathrm{C}-\mathrm{MC} / \mathrm{S}$; (b) TEM image of $\mathrm{Fe}_{3} \mathrm{C}-\mathrm{MC} / \mathrm{S}$; (c) Typical TEM image of $\mathrm{Fe}_{3} \mathrm{C}-\mathrm{MC} / \mathrm{S}$ and corresponding mapping images of $\mathrm{C}, \mathrm{N}, \mathrm{Fe}$ and $\mathrm{S}$; (d) Optical photos of different samples immersed in a $\mathrm{Li}_{2} \mathrm{~S}_{6} / \mathrm{DOL} / \mathrm{DME}$ solution after $12 \mathrm{~h}$; (e) Nyquist plots of batteries with MC and $\mathrm{Fe}_{3} \mathrm{C}-\mathrm{MC}$ as sulfur hosts before cycling; (f) Nyquist plots of batteries with $\mathrm{MC}$ and $\mathrm{Fe}_{3} \mathrm{C}-\mathrm{MC}$ as sulfur hosts after 1000 cycles; (g) Raman spectra of a blank solution without $\mathrm{Li}_{2} \mathrm{~S}_{6}, \mathrm{Li}_{2} \mathrm{~S}_{6}$ solution, $\mathrm{Li}_{2} \mathrm{~S}_{6}$ solution with $\mathrm{MC}$ and $\mathrm{Fe}_{3} \mathrm{C}-\mathrm{MC}$, respectively; (h) Optical photos of original electrodes and separators and those in $\mathrm{MC} / \mathrm{S}$ and $\mathrm{Fe}_{3} \mathrm{C}-\mathrm{MC} / \mathrm{S}$ batteries after cycling

Further, the electrochemical performances of the batteries were investigated in detail. $\mathrm{CV}$ curves of the batteries using $\mathrm{MC}$ and $\mathrm{Fe}_{3} \mathrm{C}-\mathrm{MC}$ as sulfur hosts are shown in Figure 5a. Two obvious CV curves can be seen in all the batteries, corresponding to the reduction of $\mathrm{S}_{8}$ to high-order LiPSs $\left(\mathrm{Li}_{2} \mathrm{~S}_{\mathrm{x}}, 4 \leq \mathrm{x}<8\right)$ and then to low-order 


\section{ACCEPTED MANUSCRIPT}

$\mathrm{Li}_{2} \mathrm{~S}_{2} / \mathrm{Li}_{2} \mathrm{~S}$. Meanwhile, the anodic peaks indicate the oxidation of $\mathrm{Li}_{2} \mathrm{~S}_{2} / \mathrm{Li}_{2} \mathrm{~S}$ to $\mathrm{S}_{8}$. The working potentials of $\mathrm{MC}$ and $\mathrm{Fe}_{3} \mathrm{C}-\mathrm{MC}$ batteries are 2.082 and $2.106 \mathrm{~V}$ while the charging potentials are 2.287 and $2.208 \mathrm{~V}$, respectively. Compared with MC battery, the cathodic peaks of $\mathrm{Fe}_{3} \mathrm{C}-\mathrm{MC}$ battery shift to a higher potential while the anode peak shift to a lower potential, indicating a lower over-potential of the $\mathrm{Fe}_{3} \mathrm{C}$ $\mathrm{MC}$ battery. Under a current density of $0.5 \mathrm{~A} \mathrm{~g}^{-1}$, the over-potentials of $\mathrm{MC}$ and $\mathrm{Fe}_{3} \mathrm{C}-$ MC batteries are 267 and $165 \mathrm{mV}$ respectively, revealing the redox reaction kinetics and the reversibility of $\mathrm{Fe}_{3} \mathrm{C}-\mathrm{MC}$ batteries are significantly improved. ${ }^{54}$ Moreover, the charge/discharge curves of $\mathrm{MC}$ and $\mathrm{Fe}_{3} \mathrm{C}-\mathrm{MC}$ batteries at $0.1 \mathrm{C}$ and $0.5 \mathrm{C}$ in Figure S14 also show that the over-potential of $\mathrm{Fe}_{3} \mathrm{C}-\mathrm{MC}$ battery is much lower, indicating a faster redox reaction during the charge/discharge processes. The enhanced redox reaction kinetics contributes to fast transformation of LiPSs, which is ascribed to the activation of $\mathrm{Fe}_{3} \mathrm{C}$ to $\mathrm{S}-\mathrm{S}$ bonds according to the DFT calculation and the $\mathrm{N}$ doping in the composite. ${ }^{55-57}$ The $\mathrm{CV}$ curves of $\mathrm{Fe}_{3} \mathrm{C}-\mathrm{MC}$ battery show almost overlapped shapes within 5 cycles, as shown in Figure 5b, demonstrating excellent cycling stability.

The capacity and stability of $\mathrm{MC}, \mathrm{Fe}_{3} \mathrm{C}$ and $\mathrm{Fe}_{3} \mathrm{C}-\mathrm{MC}$ as sulfur hosts for $\mathrm{Li}-\mathrm{S}$ batteries were investigated. Firstly, the rate capacities were evaluated as shown in Figure 5c. The battery with $\mathrm{Fe}_{3} \mathrm{C}-\mathrm{MC}$ as sulfur host exhibit a high initial capacity of $1530 \mathrm{~mA} \mathrm{~h} \mathrm{~g}^{-1}$ and superior reversible rate capacities of 1423, 1268, 1130, 1034, 916 and $727 \mathrm{~mA} \mathrm{~h} \mathrm{~g}^{-1}$ at current densities of $0.1 \mathrm{C}, 0.2 \mathrm{C}, 0.5 \mathrm{C}, 1 \mathrm{C}, 2 \mathrm{C}$ and $5 \mathrm{C}$ respectively, significantly better than that for the battery with MC as sulfur host $\left(1241,1089,867,658,441\right.$ and $282 \mathrm{~mA} \mathrm{~h} \mathrm{~g}^{-1}$ at current densities of $0.1 \mathrm{C}, 0.2 \mathrm{C}, 0.5 \mathrm{C}$, $1 \mathrm{C}, 2 \mathrm{C}$ and $5 \mathrm{C}$ respectively). Figure $\mathbf{5 d}$ shows the charge/discharge curves of the battery with $\mathrm{Fe}_{3} \mathrm{C}-\mathrm{MC}$ host at different current densities, showing two well-defined plateaus and high coulombic efficiency. Figure 5e shows the cycling stability of the 


\section{ACCEPTED MANUSCRIPT}

batteries at a current density of $0.5 \mathrm{C}$. It is evident that the battery with $\mathrm{Fe}_{3} \mathrm{C}-\mathrm{MC}$ host displays much better cycling stability than that with $\mathrm{MC}$ and $\mathrm{Fe}_{3} \mathrm{C}$ hosts. The battery with MC host exhibits a capacity of $1215 \mathrm{~mA} \mathrm{~h} \mathrm{~g}^{-1}$ at the first cycle and remains only $468 \mathrm{~mA} \mathrm{~h} \mathrm{~g}^{-1}$ after 600 cycles, and the one with $\mathrm{Fe}_{3} \mathrm{C}$ host exhibits a capacity of 1478 $\mathrm{mA} \mathrm{h} \mathrm{g}^{-1}$ at the first cycle and remains $642 \mathrm{~mA} \mathrm{~h} \mathrm{~g}^{-1}$ after 800 cycles. Remarkably, the battery with $\mathrm{Fe}_{3} \mathrm{C}-\mathrm{MC}$ host displays an initial capacity of $1465 \mathrm{~mA} \mathrm{~h} \mathrm{~g}^{-1}$ and preserves $920 \mathrm{~mA} \mathrm{~h} \mathrm{~g}^{-1}$ after 1000 cycles at $0.5 \mathrm{C}$, showing only $0.037 \%$ decay for per cycle (performances for different ratios of $\mathrm{Fe}_{3} \mathrm{C}-\mathrm{MC}$ see Figure $\mathbf{S 2 1}$ ). The superior performance of $\mathrm{Fe}_{3} \mathrm{C}-\mathrm{MC}$ host for Li-S battery is one of the best among all the reported batteries as far as we know (See Support Information Table S7). The coulombic efficiency of $\mathrm{Fe}_{3} \mathrm{C}-\mathrm{MC}$ battery is also close to $100 \%$. The superior performance is ascribed to the excellent conductivity, strong adsorption to LiPSs and superior catalytic activity of $\mathrm{Fe}_{3} \mathrm{C}$ nanosheets, which facilitate the anchoring and fast conversion of LiPSs. 

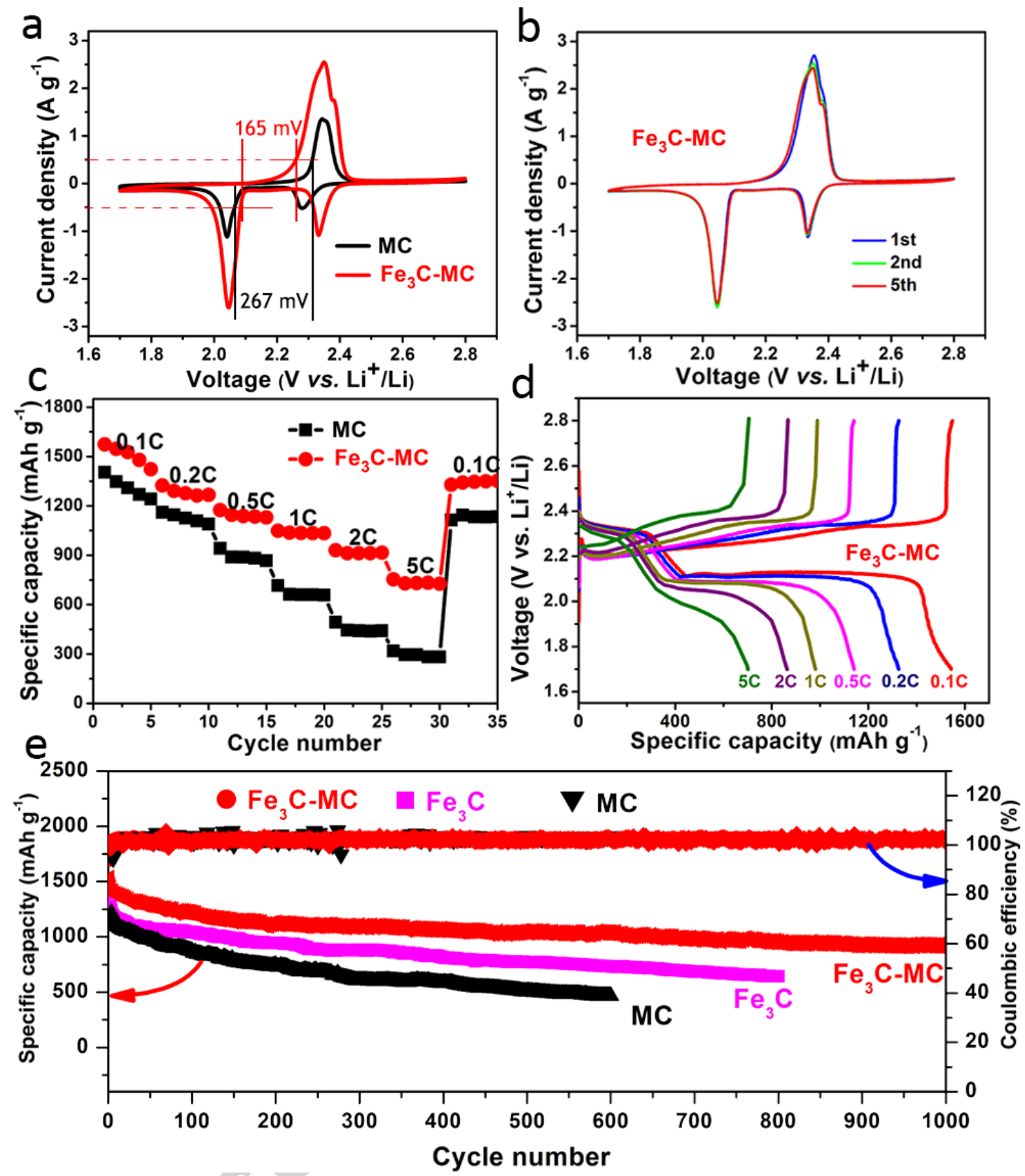

Figure 5. (a) $\mathrm{CV}$ curves of $\mathrm{MC}$ and $\mathrm{Fe}_{3} \mathrm{C}-\mathrm{MC}$ batteries; (b) $\mathrm{CV}$ curves of $\mathrm{Fe}_{3} \mathrm{C}-\mathrm{MC}$ battery from 1 st to 5 th cycle; (c) Rate performances at current densities of $0.1 \mathrm{C}, 0.2 \mathrm{C}, 0.5 \mathrm{C}, 1 \mathrm{C}, 2 \mathrm{C}$ and $5 \mathrm{C}$ with $\mathrm{MC}$ and $\mathrm{Fe}_{3} \mathrm{C}-\mathrm{MC}$ as sulfur hosts; (d) Charge/discharge curves of the battery with $\mathrm{Fe}_{3} \mathrm{C}-\mathrm{MC}$ as sulfur host at different rates within a potential window of $1.7-2.8 \mathrm{~V} \mathrm{vs}$. $\mathrm{Li}^{+} / \mathrm{Li}$; (e) Cycling stability of $\mathrm{MC}, \mathrm{Fe}_{3} \mathrm{C}$ and $\mathrm{Fe}_{3} \mathrm{C}-\mathrm{MC}$ batteries at $0.5 \mathrm{C}$ for 1000 cycles

In addition, the performances of $\mathrm{Fe}_{3} \mathrm{C}-\mathrm{MC}$ batteries with different sulfur contents (sulfur content: 80, 90 and 95 wt.\%) were investigated. Figure S15-16 present the optical images of $\mathrm{Fe}_{3} \mathrm{C}-\mathrm{MC}$, sulfur and the mixture $\left(\mathrm{Fe}_{3} \mathrm{C}-\mathrm{MC} / \mathrm{S}\right)$, indicating the 


\section{ACCEPTED MANUSCRIPT}

presence of much mesoporous structure in the $\mathrm{Fe}_{3} \mathrm{C}-\mathrm{MC}$ composite for sulfur loading. TGA analysis in Figure S18 shows that almost all of the sulfur is retained in the $\mathrm{Fe}_{3} \mathrm{C}-\mathrm{MC} / \mathrm{S}$ samples after melting diffusion treatment. The cycling stability of the batteries with $\mathrm{Fe}_{3} \mathrm{C}-\mathrm{MC} / 80 \mathrm{~S}, \mathrm{Fe}_{3} \mathrm{C}-\mathrm{MC} / 90 \mathrm{~S}$ and $\mathrm{Fe}_{3} \mathrm{C}-\mathrm{MC} / 95 \mathrm{~S}$ were tested, as shown in Figure S19, which remained 1120, 864 and $721 \mathrm{~mA} \mathrm{~h} \mathrm{~g}^{-1}$ after 200 cycles at 1C, respectively. The excellent performance indicates that the ultra-thin conductive and polar $\mathrm{Fe}_{3} \mathrm{C}$ nanosheets are able to immobilize the LiPSs and to improve redox reaction rate even at ultra-high sulfur content. Moreover, the long-term stability of $\mathrm{Fe}_{3} \mathrm{C}-\mathrm{MC}$ batteries with different sulfur loading were investigated, as shown in Figure 9. At current density of $0.5 \mathrm{C}$, capacities of $1224,1102,989,906,814$ and $699 \mathrm{~mA} \mathrm{~h} \mathrm{~g}^{-1}$ can be retained with sulfur loading of $1.5,3.0,4.5,6.0,7.5$ and $9.0 \mathrm{mg} \mathrm{cm}^{-2}$ after 100 cycles, which means specific area capacities of 1.836, 3.306, 4.451, 5.436, 6.105 and $6.291 \mathrm{mAh} \mathrm{cm}^{-2}$, respectively. In addition, the cross-sectional SEM images of the electrodes with different sulfur loading and the electrodes after 200 cycles are shown in Figure S22 and Figure S23, which show that the thickness of electrodes after cycling were only slightly increased, indicating porous structure effectively alleviate the volume expansion of $\mathrm{S}$ during charge-discharge process. The results indicates that the cost-effective production of $\mathrm{Fe}_{3} \mathrm{C}-\mathrm{MC}$ composite from biomass waste exhibits excellent performance as a sulfur host for Li-S battery not only at high sulfur content but also at high sulfur loading conditions, which provides a promising and novel strategy for commercial applications of Li-S batteries. 

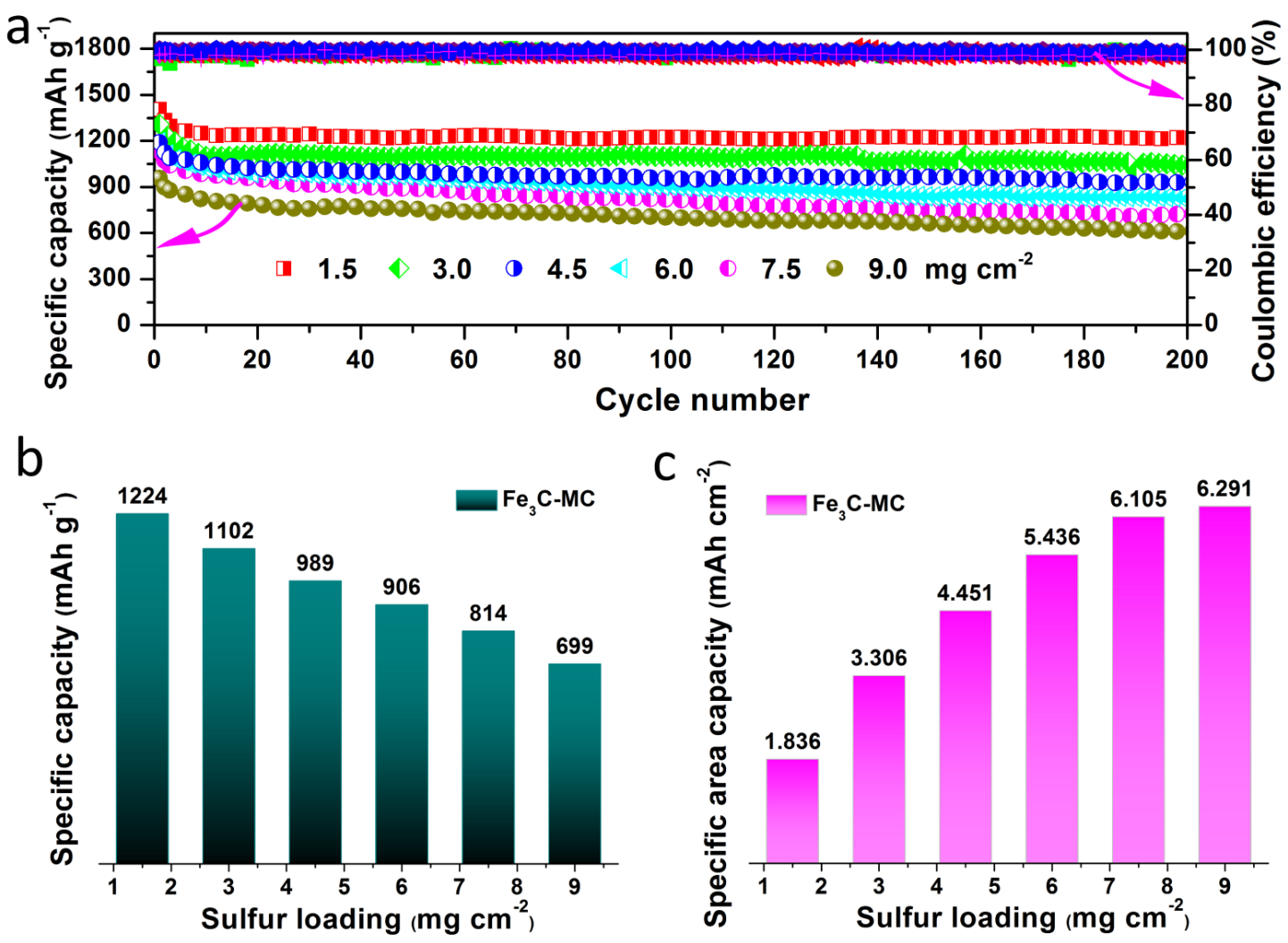

Figure 6. (a) Cycling stability of $\mathrm{Fe}_{3} \mathrm{C}-\mathrm{MC}$ battery at $0.5 \mathrm{C}$ with sulfur loading of $1.5,3.0,4.5,6.0,7.5$ and $9.0 \mathrm{mg} \mathrm{cm}^{-2}$; (b) Specific capacities and (c) specific area capacities of $\mathrm{Fe}_{3} \mathrm{C}-\mathrm{MC}$ host battery after 100 cycles with sulfur loading of $1.5,3.0,4.5,6.0,7.5$ and $9.0 \mathrm{mg} \mathrm{cm}^{-2}$

\section{CONCLUSIONS}

In summary, based on DFT calculation, we designed and synthesized a $\mathrm{Fe}_{3} \mathrm{C}-\mathrm{MC}$ composite which is composed of mesoporous carbon and ultra-thin conductive squamae-like $\mathrm{Fe}_{3} \mathrm{C}$ nanosheets, using biomass waste corncobs as basic carbon source and ferrous sulfate as iron source. The composite possesses large specific surface area of $686.9 \mathrm{~m}^{2} \mathrm{~g}^{-1}$ with pore volume of $6.52 \mathrm{~cm}^{3} \mathrm{~g}^{-1}$ and high electrical conductivity of $1.067 \mathrm{~S} \mathrm{~cm}^{-1}$. The squamae-like $\mathrm{Fe}_{3} \mathrm{C}$ nanosheets were grown on the surface of mesoporous carbon with a thickness of only $\sim 1 \mathrm{~nm}$, on which strong adsorption and rapid conversion for LiPSs were realized simultaneously. The capturing-conversion of 


\section{ACCEPTED MANUSCRIPT}

LiPSs occurred on the active sites of $\mathrm{Fe}_{3} \mathrm{C}$ simultaneously, which effectively prevented the outflow of LiPSs, leading to a low over-potential and a high reversible capacity for Li-S battery. By using this $\mathrm{Fe}_{3} \mathrm{C}-\mathrm{MC}$ composite as a sulfur host, the issues related to Li-S batteries like poor electrical conductivity, LiPSs shuttling and slow redox reaction are addressed almost simultaneously. As a result, the $\mathrm{Fe}_{3} \mathrm{C}-\mathrm{MC}$ cathode delivered a high initial capacity of $1530 \mathrm{~mA} \mathrm{~h} \mathrm{~g}^{-1}$ under the current density of 0.1C, and also, superior reversible capacities of 1423, 1268, 1130, 1034, 916 and 727 $\mathrm{mA} \mathrm{h} \mathrm{g}^{-1}$ at current densities of $0.1 \mathrm{C}, 0.2 \mathrm{C}, 0.5 \mathrm{C}, 1 \mathrm{C}, 2 \mathrm{C}$ and $5 \mathrm{C}$, respectively. After 1000 cycles at $0.5 \mathrm{C}$, a capacity of $920 \mathrm{~mA} \mathrm{~h} \mathrm{~g}^{-1}$ was still retained at a high sulfur content of $80 \mathrm{wt} . \%\left(1465 \mathrm{~mA} \mathrm{~h} \mathrm{~g}^{-1}\right.$ at the first cycle), resulting in a very low capacity decay of $0.037 \%$ per cycle. Moreover, at a super high sulfur loading of $9.0 \mathrm{mg} \mathrm{cm}^{-2}$, a capacity of $699 \mathrm{~mA} \mathrm{~h} \mathrm{~g}^{-1}$ is still preserved after 100 cycles at $0.5 \mathrm{C}$, which means a specific area capacity of $6.291 \mathrm{~mA} \mathrm{~h} \mathrm{~cm}^{-2}$. Such a sulfur host is expected to promote the practical use of Li-S batteries because of the low cost of sources, large-scale process and promising performances. The preparation approach of the sulfur host also suggests a new way to produce multifunctional sulfur host to improve the performance of energy storage device.

\section{EXPERIMENTAL SECTION}

DFT calculation for the LiPSs adsorption: Calculations were performed using DFT implemented in the Vienna Ab initio Simulation Package (VASP). ${ }^{21}$ The projected augmented wave potential ${ }^{22}$ and generalized functional ${ }^{23}$ were used to describe the electron-ion interaction and exchange-correlation energy, respectively. The plane-wave cutoff energy was set to be $300 \mathrm{eV}$. The periodically repeated unit cells were $13.50 \AA \times 13.62 \AA$ with 5 atomic layers. The k-point used in sampling for 
orthogonal $\mathrm{Fe}_{3} \mathrm{C}(220),(-220)$ and (002) planes were $8 \times 8 \times 1$ grids. A vacuum distance larger than $10 \AA$ was used to remove the interaction between successive slabs. In structural optimization, the lower half of the slabs were fixed to their bulk truncated positions allowing all other atoms to fully relax until the force converged to 0.01 $\mathrm{eV} / \AA^{24} .^{24}$ The adsorption energy $\left(\mathrm{E}_{\mathrm{ads}}\right)$ for $\mathrm{Li}_{2} \mathrm{~S}_{6}$ on the $\mathrm{Fe}_{3} \mathrm{C}$ surface was defined as $\mathrm{E}_{\mathrm{ads}}$ $=E_{t o l}-E_{L S}-E_{\text {sur }}$, where $E_{\text {tol }}$ is the total energy of the adsorbed system, $E_{L S}$ is the energy of $\mathrm{Li}_{2} \mathrm{~S}_{6}$ in vacuum and $\mathrm{E}_{\text {sur }}$ is the energy of the optimized clean $\mathrm{Fe}_{3} \mathrm{C}$ surface slab. ${ }^{25}$ The specific surface energies are calculated with the formula: Esur $=\left(E_{\text {slab }}-n\right.$ $\left.\mathrm{E}_{\text {bulk }}\right) / 2 \mathrm{~A}$, where $\mathrm{E}_{\text {slab }}$ is the energy of the slab, $\mathrm{E}_{\text {bulk }}$ is the energy of a unit cell, $\mathrm{n}$ is the number of unit cells and $\mathrm{A}$ is the area of the surface.

Synthesis of $\mathrm{Fe}_{3} \mathrm{C}-\mathrm{MC}$ : Firstly, biomass waste, corncob, was pretreated using the method reported previously. ${ }^{7}$ Typically, corncob was ball-milled to fine powders, and then pretreated with concentrated sulfuric acid at $60^{\circ} \mathrm{C}$ for 2 hours until yellow powders turned into black. After being thoroughly washed and dried, the pretreated corncob was mixed with ferrous sulfate homogeneously. Finally, the mixture was annealed at $800{ }^{\circ} \mathrm{C}$ for 2 hours in a quartz tube furnace under $\mathrm{N}_{2}$ atmosphere and then $\mathrm{Fe}_{3} \mathrm{C}-\mathrm{MC}$ composite was obtained. The resultant $\mathrm{Fe}_{3} \mathrm{C}-\mathrm{MC}$ composites with different ferrous sulfate mass ratios ( $\mathrm{Fe}_{3} \mathrm{C}-\mathrm{MC}-\mathrm{x}, \mathrm{x}$ is the mass ratios of ferrous sulfate) were illustrated in Support Information (BET: Figure S10; ICP-AES and EDS: Table S5). For comparison, mesoporous carbon (MC) was also prepared by annealing the pretreated corncob without addition of ferrous sulfate.

Materials characterization: The prepared carbon materials were examined using scanning electron microscopy (SEM, Hitachi S-4800, Japan) and high resolution transmission electron microscopy (HRTEM, JEM-2100F, Japan) equipped with energy-dispersive X-ray spectrometer (EDS). High-angle annular dark-field 


\section{ACCEPTED MANUSCRIPT}

scanning transmission electron microscopy (HAADF-STEM) was also used to investigate the element distribution. X-ray diffraction (XRD) patterns were obtained using the X-ray diffractometer (Philips PC-APD) with $\mathrm{Cu} \mathrm{K \alpha}$ radiation $(\lambda=1.5418 \AA$ ) operating at $40 \mathrm{kV}, 60 \mathrm{~mA}$. X-ray photoelectron spectroscopy (XPS) analysis was performed on the ESCALAB250 XPS spectrometer with a Mg Ka X-ray source (1350 eV). Fourier transform infrared spectroscopy (FTIR) analysis was carried out using a Fourier transform infrared spectrometer (FTIR-5300). Brunauer Emmett Teller (BET) specific surface areas were calculated based on the nitrogen physical adsorption (Beckman Coulter SA-3100, USA). Atomic force microscopy (AFM) analysis was conducted using a NT-MDT Ntegra Solaris instrument. The content of Fe in the composite was measured by inductively coupled plasma atomic emission spectrometry (ICP-AES). The electrical conductivity of the electrodes was measured by a standard four point probe resistivity measurement system (RTS-9, Guangzhou, China). Thermogravimetric analysis (TGA) was conducted on a simultaneous DSCTGA analyzer (NETZSCH-409PC) from $20^{\circ} \mathrm{C}$ to $900{ }^{\circ} \mathrm{C}$ in air atmosphere to determine the content of $\mathrm{Fe}_{3} \mathrm{C}$ in the composite, while performed from $20{ }^{\circ} \mathrm{C}$ to 500 ${ }^{\circ} \mathrm{C}$ with a heating rate of $5^{\circ} \mathrm{C} \mathrm{min}^{-1}$ in the $\mathrm{N}_{2}$ atmosphere to evaluate the sulfur content of each electrode.

Electrochemical measurements of lithium sulfur batteries: Electrochemical experiments were performed using 2025 type coin cells. The working electrode was prepared by adding sulfur cathode material into the $\mathrm{MC}$ or $\mathrm{Fe}_{3} \mathrm{C}-\mathrm{MC}$ active material film to form $\mathrm{MC} / \mathrm{S}$ or $\mathrm{Fe}_{3} \mathrm{C}-\mathrm{MC} / \mathrm{S}$ electrode. The electrolyte was $0.5 \mathrm{M}$ lithium bistrifluoromethanesulfonylimide (LiTFSI) dissolved in a mixed solvent of 1, 3dioxolane and 1, 2-dimethoxyethane (DOL/DME, 1:1, v/v). The sulfur loading are range from 1.5 to $9.0 \mathrm{mg} \mathrm{cm}^{-2}$, and the amount of the electrolyte used in assembling 


\section{ACCEPTED MANUSCRIPT}

each cell was $\sim 6 \mu \mathrm{L} / \mathrm{mgS}$. Galvanostatic charge-discharge measurements were performed at room temperature in a potential range of $1.7-2.8 \mathrm{~V}\left(\mathrm{vs}^{\mathrm{Li}} \mathrm{Li}^{+} / \mathrm{Li}\right)$ at $0.1 \mathrm{C}$, $0.2 \mathrm{C}, 0.5 \mathrm{C}, 1 \mathrm{C}, 2 \mathrm{C}$, and $5 \mathrm{C}\left(1 \mathrm{C}=1672 \mathrm{~mA} \mathrm{~g}^{-1}\right)$ with a battery tester (LAND CT2001A, China). Cyclic voltammetry (CV) was performed with an electrochemical workstation (CHI 660C) between 1.7 and $2.8 \mathrm{~V}$ at a scan rate of $0.1 \mathrm{mV} \mathrm{s}^{-1}$. Electrochemical impedance spectroscopy (EIS) analysis was conducted using the same equipment from $10^{5} \mathrm{~Hz}$ to $10^{-2} \mathrm{~Hz}$.

\section{ASSOCIATED CONTENT}

\section{Notes}

The authors declare no competing financial interest.

\section{ACKNOWLEDGEMENTS}

This work is supported by National Natural Science Foundation of China (Grant No. 51672075, 51704106, 51772092). National Supercomputing Center in CHANGSHA is acknowledged for allowing the use of computational resources including TIANHE1. Professor Xiaorong Zhou from The University of Manchester, UK is appreciated for polishing the language during the preparation of this manuscript.

\section{REFERENCES}

1. Liu, M.; Qin, X.; He, Y. B.; Li, B.; Kang, F. Recent innovative configurations in high-energy lithium-sulfur batteries. J. Mater. Chem. A, 2017, 5, 5222-5234.

2. $\quad$ Chen, L.; Feng, J.; Zhou, H.; Fu, C.; Wang, G.; Yang, L.; Xu, C.; Chen, Z.; Yang, W.; Kuang, Y. Hydrothermal preparation of nitrogen, boron co-doped curved 


\section{ACCEPTED MANUSCRIPT}

graphene nanoribbons with high dopant amounts for high-performance lithium sulfur battery cathodes. J. Mater. Chem. A, 2017, 5, 7403-7415.

3. Gong, Y., Fu, C., Zhang, G., Zhou, H.; Kuang, Y. Three-dimensional Porous $\mathrm{C}_{3} \mathrm{~N}_{4}$ Nanosheets@ Reduced Graphene Oxide Network as Sulfur Hosts for High Performance Lithium-Sulfur Batteries. Electrochim. Acta, 2017, 256, 1-9.

4. Zhou, G., Li, L., Wang, D. W., Shan, X. Y., Pei, S., Li, F., Cheng, H. M. A flexible sulfur-graphene-polypropylene separator integrated electrode for advanced Li-S batteries. Adv. Mater. 2015, 27, 641-647.

5. Wang, Y. X., Huang, L., Sun, L. C., Xie, S. Y., Xu, G. L., Chen, S. R., Xu, Y. F.; Li, J. T.; Chou, S. L.; Dou, S. X.; Sun, S. G. Facile synthesis of a interleaved expanded graphite-embedded sulphur nanocomposite as cathode of Li-S batteries with excellent lithium storage performance. J. Mater. Chem. 2012, 22, 4744-4750.

6. Elazari, R., Salitra, G., Garsuch, A., Panchenko, A., Aurbach, D. Sulfurimpregnated activated carbon fiber cloth as a binder-free cathode for rechargeable LiS batteries. Adv. Mater. 2011, 23, 5641-5644.

7. Li, H., Gong, Y., Fu, C., Zhou, H., Yang, W., Guo, M., Li, M.; Kuang, Y. A novel method to prepare a nanotubes@ mesoporous carbon composite material based on waste biomass and its electrochemical performance. J. Mater. Chem. A, 2017, 5, 3875-3887.

8. Zhou, G., Li, L., Ma, C., Wang, S., Shi, Y., Koratkar, N.; Ren, W.; Li, F.;

Cheng, H. M. A graphene foam electrode with high sulfur loading for flexible and high energy Li-S batteries.Nano Energy, 2015, 11, 356-365.

9. Lyu, Z.; Xu, D.; Yang, L.; Che, R.; Feng, R.; Zhao, J.; Li, Y.; Wu, Q.; Wang, X.; Hu, Z. Hierarchical carbon nanocages confining high-loading sulfur for high-rate lithium-sulfur batteries. Nano Energy, 2015, 12, 657-665. 


\section{ACCEPTED MANUSCRIPT}

10. Zhao, M.; Liu, X.; Zhang, Q.; Tian, G.; Huang, J.; Zhu, W.; Wei, F.;

Graphene/single-walled carbon nanotube hybrids: one-step catalytic growth and applications for high-rate Li-S batteries. ACS nano, 2012, 6, 10759-10769.

11. Wang, D.; Zhou, G.; Li, F.; Wu, K.; Lu, G.; Cheng, H.; Gentle, I. R. A microporous-mesoporous carbon with graphitic structure for a high-rate stable sulfur cathode in carbonate solvent-based Li-S batteries. Phys. Chem. Chem. Phys. 2012, 14, 8703-8710.

12. Chen, R.; Zhao, T.; Lu, J.; Wu, F.; Li, L.; Chen, J.; Tan, G.; Ye, Y.; Amine, K. Graphene-based three-dimensional hierarchical sandwich-type architecture for highperformance Li/S batteries. Nano Lett. 2013, 13, 4642-4649.

13. Hu, G.; Xu, C.; Sun, Z.; Wang, S.; Cheng, H. M.; Li, F.; Ren, W. Adv. Mater. 2016, 28, 1603-1609.

14. Sun, J.; Sun, Y.; Pasta, M.; Zhou, G.; Li, Y.; Liu, W.; Xiong, F.; Cui, Y. 3D Graphene-Foam-Reduced-Graphene-Oxide Hybrid Nested Hierarchical Networks for High-Performance Li-S Batteries. Adv. Mater. 2016, 28, 9797-9803.

15. Liang, J.; Yin, L.; Tang, X.; Yang, H.; Yan, W.; Song, L.; Cheng, H.-M.; Li, F. ACS Appl. Mat. Inter. 2016, 8, 25193-25201.

16. Deng, D.; Xue, F.; Jia, Y.; Ye, J.; Bai, C.; Zheng, M.; Dong, Q. Co4N Nanosheet Assembled Mesoporous Sphere as a Matrix for Ultrahigh Sulfur Content Lithium-Sulfur Batteries. ACS nano, 2017, 11, 6031.

17. Zhou, T.; Lv, W.; Li, J.; Zhou, G.; Zhao, Y.; Fan, S.; Liu, Li B.; B.; Kang, F.; Yang, Q. Twinborn $\mathrm{TiO}_{2}$-TiN heterostructures enabling smooth trapping-diffusionconversion of polysulfides towards ultralong life lithium-sulfur batteries. Energy Environ. Sci. 2017, 10, 1694-1703. 


\section{ACCEPTED MANUSCRIPT}

18. Liang, Z.; Zheng, G.; Li, W.; Seh, Z. W.; Yao, H.; Yan, K.; Kong, D.; Cui, Y.

Sulfur cathodes with hydrogen reduced titanium dioxide inverse opal structure. ACS nano, 2014, 8, 5249-5256.

19. Li, Y.; Fan, J.; Zhang, J.; Yang, J.; Yuan, R.; Chang, J.; Zheng, M.; Dong, Q. A Honeycomb-like Co@N-C Composite for Ultrahigh Sulfur Loading Li-S Batteries. ACS nano, 2017, 11, 11417.

20. Li, Y.; Fan, J.; Zheng, M.; Dong, Q.; A novel synergistic composite with multi-functional effects for high-performance Li-S batteries. Energy Environ. Sci. 2016, 9, 1998-2004.

21. Neaton, J.; Ashcroft, N.; Pairing in dense lithium. Nature, 1999, 400, 141-144.

22. Kresse, G.; Joubert, D.; From ultrasoft pseudopotentials to the projector augmented-wave method. Phys. Rev. B, 1999, 59, 1758.

23. Xia, Y.; Qian, D.; Hsieh, D.; Wray, L.; Pal, A.; Lin, H.; Bansil, A.; Grauer, D.; Hor, Y. S.; Cava, R. J. Observation of a large-gap topological-insulator class with a single Dirac cone on the surface. Nat. Phys. 2009, 5, 398-402.

24. Zhou, G.; Tian, H.; Jin, Y.; Tao, X.; Liu, B.; Zhang, R.; Seh, Z. W.; Zhuo, D.; Liu, Y.; Sun, J. Catalytic oxidation of $\mathrm{Li}_{2} \mathrm{~S}$ on the surface of metal sulfides for Li-S batteries. Proc. Natl. Acad. Sci. 2017, 114, 840-845.

25. Xie, J.; Peng, H.; Huang, J.; Xu, W.; Chen, X.; Zhang, Q. A Supramolecular Capsule for Reversible Polysulfide Storage/Delivery in Lithium-Sulfur Batteries. Angew. Chem. Int. Edit. 2017, 124, 10251.

26. Chen, J.; Yuan, R.; Feng, J.; Zhang, Q.; Huang, J.; Fu, G.; Zheng, M.; Ren, B.; Dong, Q. Conductive Lewis Base Matrix to Recover the Missing Link of $\mathrm{Li}_{2} \mathrm{~S}_{8}$ during the Sulfur Redox Cycle in Li-S Battery. Chem. Mater. 2015, 27, 2048-2055. 


\section{ACCEPTED MANUSCRIPT}

27. Gu, X.; Lai, C. Recent development of metal compound applications in lithium-sulphur batteries. J. Mater. Res. 2017, 33, 1-16.

28. Zhong, Y.; Yang, K. R.; Liu, W.; He, P.; Batista, V. S.; Wang, H. Mechanistic insights into surface chemical interactions between lithium polysulfides and transition metal oxides. J. Phys. Chem. C, 2017, DOI: 10.1021/acs.jpcc.7b04170.

29. Zhang, Q.; Wang, Y.; Seh, Z. W.; Fu, Z.; Zhang, R.; Cui, Y. Understanding the anchoring effect of two-dimensional layered materials for lithium-sulfur batteries. Nano Lett. 2015, 15, 3780-3786.

30. Al Salem, H.; Babu, G.; Rao, C. V.; Arava, L. Electrocatalytic polysulfide traps for controlling redox shuttle process of Li-S batteries. J. Am. Chem. Soc. 2015, $137,11542-11545$.

31. Khalili, N. R.; Campbell, M.; Sandi, G.; Golaś, J. Production of micro-and mesoporous activated carbon from paper mill sludge: I. Effect of zinc chloride activation. Carbon, 2000, 38, 1905-1915.

32. Liou, T. Development of mesoporous structure and high adsorption capacity of biomass-based activated carbon by phosphoric acid and zinc chloride activation. Chem. Eng. J. 2010, 158, 129-142.

33. Lv, Y.; Zhang, F.; Dou, Y.; Zhai, Y.; Wang, J.; Liu, H.; Xia, Y.; Tu, B.; Zhao, D. A comprehensive study on $\mathrm{KOH}$ activation of ordered mesoporous carbons and their supercapacitor application. J. Mater. Chem. 2012, 22, 93-99.

34. Adinata, D.; Daud, W.; Aroua, M. K. Bioresource Technol. 2007, 98, 145-149. 35. Foo, K.; Hameed, B. Preparation and characterization of activated carbon from palm shell by chemical activation with $\mathrm{K}_{2} \mathrm{CO}_{3}$. Bioresource Technol. 2012, 111, 425432. 


\section{ACCEPTED MANUSCRIPT}

36. Lee, J. S.; Park, G. S.; Kim, S. T.; Liu, M.; Cho, J. A highly efficient

electrocatalyst for the oxygen reduction reaction: $\mathrm{N}$ - doped ketjenblack incorporated into $\mathrm{Fe} / \mathrm{Fe}_{3} \mathrm{C}$-functionalized melamine foam. Angew. Chem. Int. Edit. 2013, 125, 1060-1064.

37. Yang, W.; Liu, X.; Yue, X.; Jia, J.; Guo, S. Bamboo-like Carbon Nanotube/ $\mathrm{Fe}_{3} \mathrm{C}$ Nanoparticle Hybrids and Their Highly Efficient Catalysis for Oxygen Reduction. J. Am. Chem. Soc. 2015, 137, 1436-1439.

38. Wen, Z.; Ci, S.; Zhang, F.; Feng, X.; Cui, S.; Mao, S.; Luo, S.; He, Z.; Chen, J. Nitrogen-enriched core-shell structured $\mathrm{Fe} / \mathrm{Fe}_{3} \mathrm{C}-\mathrm{C}$ nanorods as advanced electrocatalysts for oxygen reduction reaction. Adv. Mater. 2012, 24, 1399-1404.

39. Hou, Y.; Huang, T.; Wen, Z.; Mao, S.; Cui, S.; Chen, J. Metal-Organic Framework-Derived Nitrogen-Doped Core-Shell-Structured Porous $\mathrm{Fe} / \mathrm{Fe}_{3} \mathrm{C} @ \mathrm{C}$ Nanoboxes Supported on Graphene Sheets for Efficient Oxygen Reduction Reactions. Adv. Energy Mater. 2014, 4, 1220.

40. Sun, C.; Guo, Y.; Xu, X.; Du, Q.; Duan, H.; Chen, Y.; Li, H.; Liu, H. In situ preparation of carbon/ $\mathrm{Fe}_{3} \mathrm{C}$ composite nanofibers with excellent electromagnetic wave absorption properties. Compos Part A: Appl Sci Manufac, 2017, 92, 341.

41. Li, H.; Huang, Y.; Zhou, H.; Yang, W.; Li, M.; Huang, Z.; Fu, C.; Kuang, Y. One step in-situ synthesis of Co@ N, S co-doped CNTs composite with excellent HER and ORR bi-functional electrocatalytic performances. Electrochim. Acta, 2017, 247, 736-744.

42. Sun, F.; Wang, J.; Long, D.; Qiao, W.; Ling, L.; Lv, C.; Cai, R. A high-rate lithium-sulfur battery assisted by nitrogen-enriched mesoporous carbons decorated with ultrafine $\mathrm{La}_{2} \mathrm{O}_{3}$ nanoparticles. J. Mater. Chem. A, 2013, 1, 13283-13289. 


\section{ACCEPTED MANUSCRIPT}

43. Kong, W.; Yan, L.; Luo, Y.; Wang, D.; Jiang, K.; Li, Q.; Fan, S.; Wang, J.

Ultrathin $\mathrm{MnO}_{2} /$ Graphene Oxide/Carbon Nanotube Interlayer as Efficient

Polysulfide-Trapping Shield for High-Performance Li-S Batteries. Adv. Funct. Mater. $2017,27,1606663$.

44. Zheng, C.; Niu, S.; Lv, W.; Zhou, G.; Li, J.; Fan, S.; Deng, Y.; Pan, Z.; Li, B.; Kang, F. Propelling polysulfides transformation for high-rate and long-life lithiumsulfur batteries. Nano Energy, 2017, 33, 306-312.

45. Yuan, Z.; Peng, H.; Hou, T.; Huang, J.; Chen, C.; Wang, D.; Cheng, X.; Wei, F.; Zhang, Q. Powering lithium-sulfur battery performance by propelling polysulfide redox at sulfiphilic hosts. Nano Lett. 2016, 16, 519-527.

46. Pu, J.; Shen, Z.; Zheng, J.; Wu, W.; Zhu, C.; Zhou, Q.; Zhang, H.; Pan, F. Multifunctional $\mathrm{Co}_{3} \mathrm{~S}_{4} @$ sulfur nanotubes for enhanced lithium-sulfur battery performance. Nano Energy, 2017, 37, 7-14.

47. Babu, G.; Masurkar, N.; Al Salem, H.; Arava, L. Transition metal dichalcogenide atomic layers for lithium polysulfides electrocatalysis. J. Am. Chem. Soc. 2016, 139, 171-178.

48. Li, X.; Liu, J.; Wang, B.; Banis, M. N.; Xiao, B.; Li, R.; Sham, T.-K.; Sun, X. Nanoscale stabilization of Li-sulfur batteries by atomic layer deposited $\mathrm{Al}_{2} \mathrm{O}_{3} . R S C$ Adv. 2014, 4, 27126-27129.

49. Han, X.; Xu, Y.; Chen, X.; Chen, Y.; Weadock, N.; Wan, J.; Zhu, H.; Liu, Y.; Li, H.; Rubloff, G. Reactivation of dissolved polysulfides in Li-S batteries based on atomic layer deposition of $\mathrm{Al}_{2} \mathrm{O}_{3}$ in nanoporous carbon cloth. Nano Energy, 2013, 2, 1197-1206. 


\section{ACCEPTED MANUSCRIPT}

50. Yu, M.; Yuan, W.; Li, C.; Hong, J.; Shi, G. Performance enhancement of a graphene-sulfur composite as a lithium-sulfur battery electrode by coating with an ultrathin $\mathrm{Al}_{2} \mathrm{O}_{3}$ film via atomic layer deposition. J. Mater. Chem. A, 2014, 2, 7360.

51. Ma, L.; Wei, S.; Zhuang, H. L.; Hendrickson, K. E.; Hennig, R. G.; Archer, L. A. Hybrid cathode architectures for lithium batteries based on $\mathrm{TiS}_{2}$ and sulfur. $J$. Mater. Chem. A, 2015, 3, 19857-19866.

52. Seh, Z. W.; Yu, J. H.; Li, W.; Hsu, P.-C.; Wang, H.; Sun, Y.; Yao, H.; Zhang, Q.; Cui, Y. Two-dimensional layered transition metal disulphides for effective encapsulation of high-capacity lithium sulphide cathodes. Nat. Commun. 2014, 5, 5017.

53. Cui, Z.; Zu, C.; Zhou, W.; Manthiram, A.; Goodenough, J. B.; Mesoporous Titanium Nitride-Enabled Highly Stable Lithium-Sulfur Batteries. Adv. Mater. 2016, 28, 6926-6931.

54. Liu, D.; Zhang, C.; Zhou, G.; Lv, W.; Ling, G.; Zhi, L.; Yang, Q. H. Catalytic Effects in Lithium-Sulfur Batteries: Promoted Sulfur Transformation and Reduced Shuttle Effect. Adv. Sci. 2017. DOI: 10.1002/advs.201700270

55. Li, L.; Zhou, G.; Yin, L.; Koratkar, N.; Li, F.; Cheng, H.-M. Stabilizing sulfur cathodes using nitrogen-doped graphene as a chemical immobilizer for Li-S batteries, Carbon. 2016, 108, 120-126.

56. Zhou, G. M.; Paek, E.; Hwang, G. S.; Manthiraml, A. Long-life Li/polysulphide batteries with high sulphur loading enabled by lightweight three-dimensional nitrogen/sulphur-codoped graphene sponge, Nat. Commun. 2015, 6, 7760.

57. Zhou, G.; Paek, E.; Hwang, G. S.; Manthiram, A. High-Performance LithiumSulfur Batteries with a Self-Supported, 3D $\mathrm{Li}_{2} \mathrm{~S}$-Doped Graphene Aerogel Cathodes. Adv. Energy Mater. 2016, 6, 1501355 


\section{ACCEPTED MANUSCRIPT}

\section{TOC GRAPHIC:}

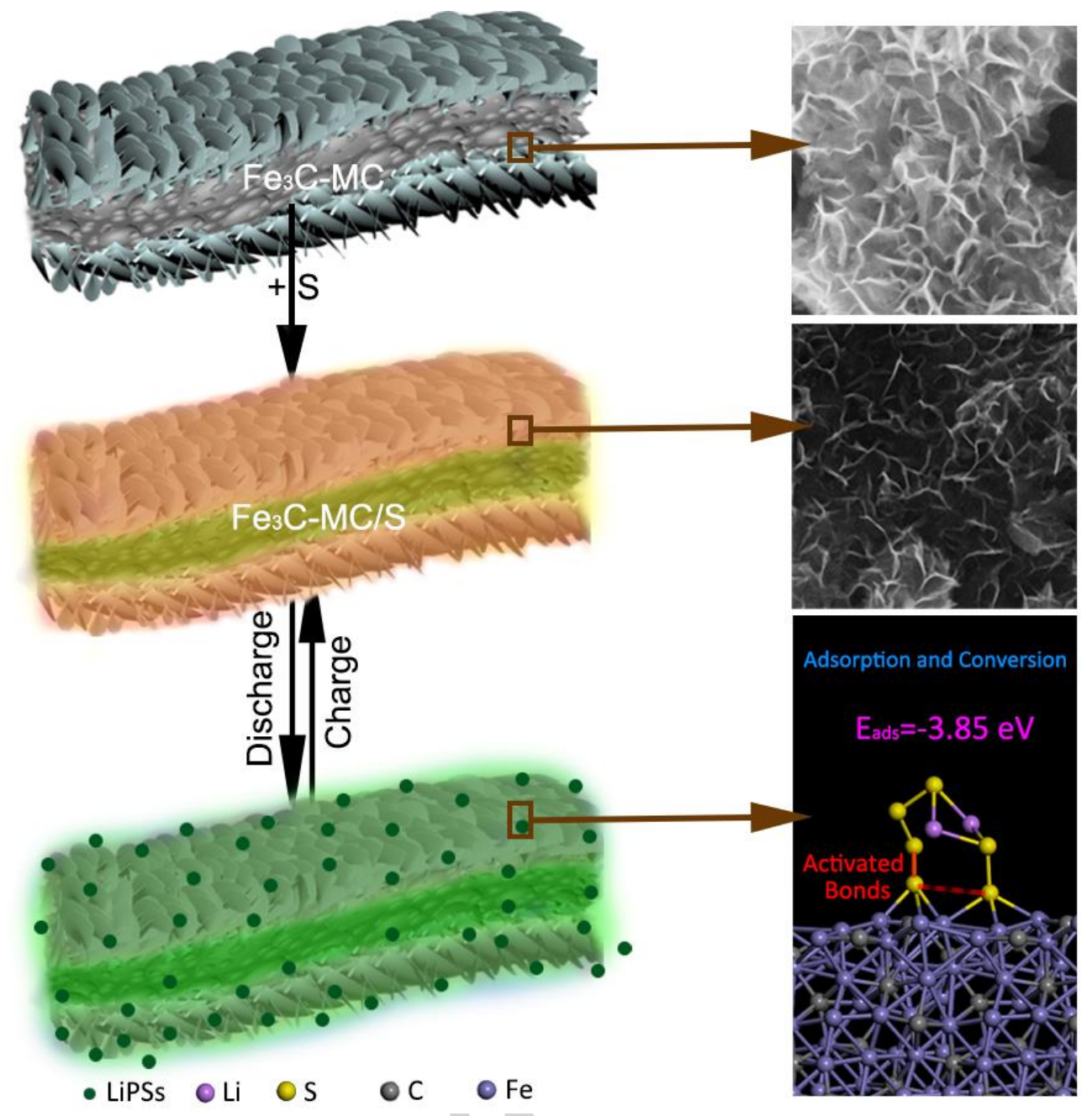

Ultra-thin $\mathrm{Fe}_{3} \mathrm{C}$ nanosheets@mesoporous carbon $\left(\mathrm{Fe}_{3} \mathrm{C}-\mathrm{MC}\right)$ composite is prepared for lithium sulfur batteries based on biomass waste. The $\mathrm{Fe}_{3} \mathrm{C}-\mathrm{MC}$ composite possesses high conductivity, large specific surface area $\left(686.9 \mathrm{~m}^{2} \mathrm{~g}^{-1}\right)$, strong adsorption ability and excellent catalytic activity to lithium polysulfides, which addresses the major issues of lithium sulfur batteries in a low-cost and large-scale way. 